\title{
The molecular genetics of neurofibromatosis type 1 and its future prospective
}

Mohammad Reza Nooridaloii ${ }^{1}$, Elham Boustanipour ${ }^{2}$

${ }^{I}$ Full Professor, Department of Medical Genetics, Faculty of Medicine Tehran of Medical Sciences, Tehran, Iran

${ }^{2}$ MSc Student, Department of Medical Genetics, Faculty of Medicine Tehran of Medical Sciences, Tehran, Iran

\begin{abstract}
Neurofibromatosis type 1 (NF1) is an autosomal dominant tumor predisposition syndrome that is caused through loss of function mutations of a tumor suppressor gene termed neurofibromin 1. Therapeutic decisions are presently restricted for NF1-associated tumors, where treatment is often restricted to thorough surgical resection with perfect margins. In this review article, the multifunctional role of neurofibromin in tumor suppression has been discussed. While neurofibromin inhibits proliferative growth through blockade RAS-mediated signal transduction, neurofibromin should also be considered as a modulator of cell motility and cell adhesion. Through interfacing with the cytoskeleton and membrane structures, neurofibromin acts as a negative regulator of RHO/ROCK signaling pathways involved in cytoskeletal dynamics that are involved in proper neuronal expansion.

The loss of function of neurofibromin through genetic mutation results in heightened cell proliferation and migration, predisposing NF1 patients to cancer. Malignant peripheral nerve sheath tumors (MPNSTs) can be developed from benign neurofibromas and are the main cause of death amongst NF1 patients. Recent researchers in MPNSTs have been attempting to reveal key molecular events that lead MPNSTs to malignancy. Advances regarding malignant drivers involved in cell migration, cell invasion and angiogenic signaling are discussed in this review, where these findings will likely influence future therapies for both NF1 and related sporadic cancers.
\end{abstract}

Keywords: Neurofibromatosis type 1, Plexiform Neurofibromatosis, MPNST.

Cited as: Nooridaloiia MR, Boustanipourb E. The molecular genetics of neurofibromatosis type 1 and its future prospective. Medical Science Journal of Islamic Azad University, Tehran Medical Branch 2019; 29(2): 101-116.

Correspondence to: Mohammad Reza Nooridaloii

Tel: +982188953005

E-mail: nooridaloii@sina.tums.ac.ir

ORCID ID: 0000-0002-9044-9842

Received: 26 Nov 2018; Accepted: 13 Jan 2019 
مجله علوم يزشكى دانشگاه آزاد اسلامى

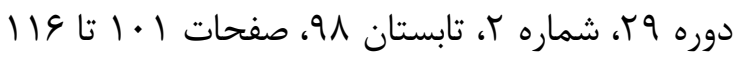

Review

Article

\section{زنتيك مولكولى نوروفيبروماتوز ا و جششم انداز \\ محمدرضا نورى دلوئى'، الهام بوستانى يور}

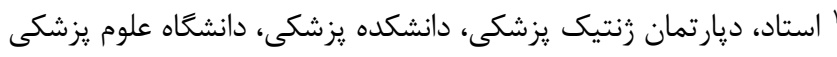

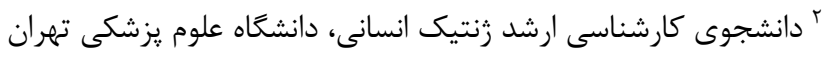

نوروفيبروماتوز تيب ا (NF1) يكى نشانكان مستعد به تومور غالب اتوزومى است كه با رخداد جهش و در نتيجه، از دست دادن كاركرد

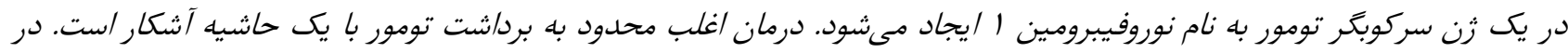

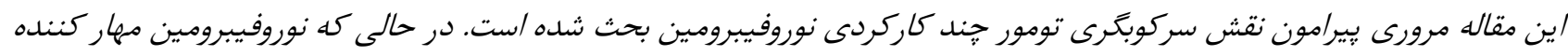

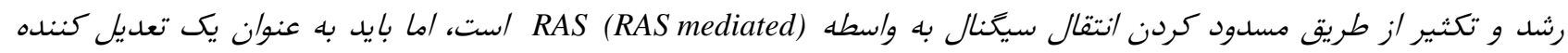

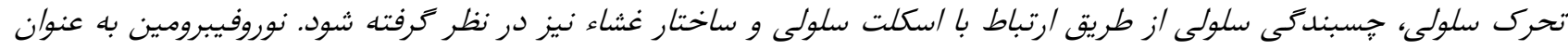

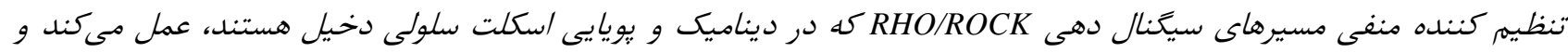

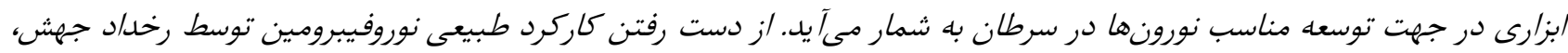

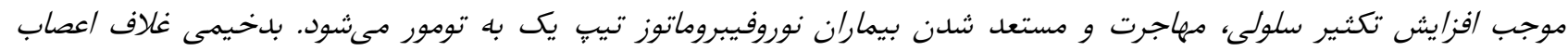
محيطى تومورها (MPNSTS قادر است /ز نوروفيبروماتوز خوشخيم كسترش يابد. رخدادى كه دليل اصلى مركى بين بيماران

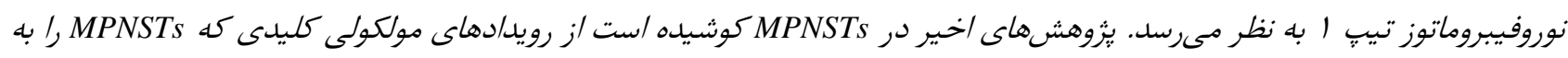

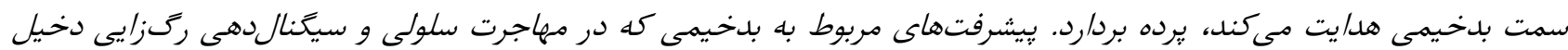

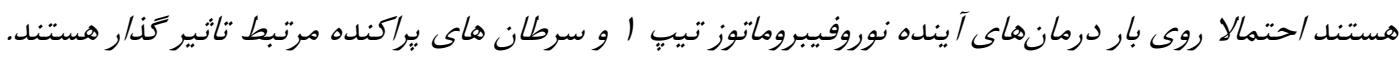

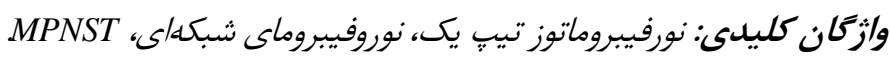

با نام نوروفيبروماتوزيس معرفى شد (l، ؟). NF1،

مستعد كننده تومور همراه با وارثت غالب اتوزومى است و ثن

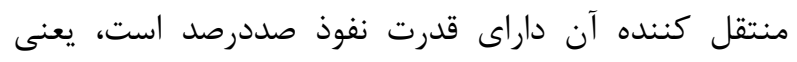

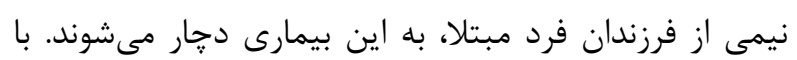

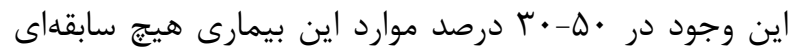

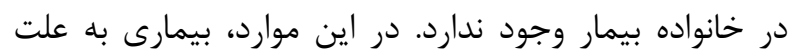

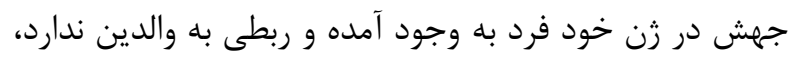

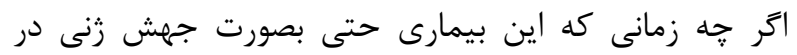
فردى ايجاد شود مىتواند به فرزندان او هم منتقل شود.

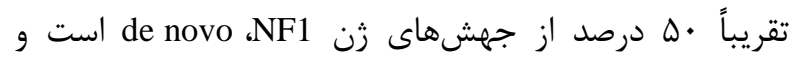

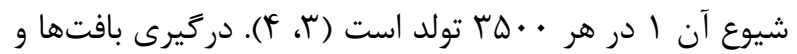
اندامهاى متفاوت و نيز شدت بيمارى بين مبتلايان بسته به
نوروفيبروماتوزيس (NF1: Neurofibromatosis) نوعى بيمارى زنتيكى است كه اعصاب و يوست را گرفتار مى كند. در اين

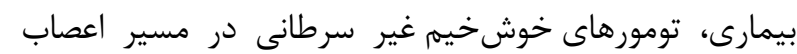

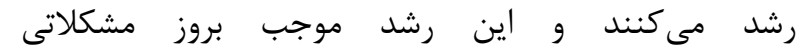

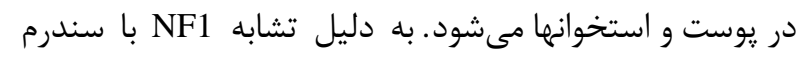

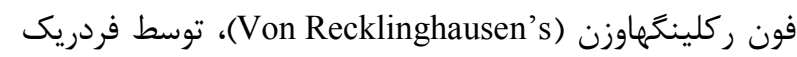
دانيل (Friedrich Daniel Recklinghausen) در سال

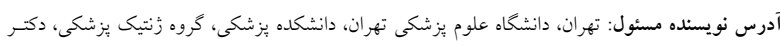

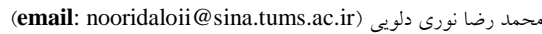
ORCID ID: 0000-0002-9044-9842 تاريخ دريافت مقاله: 9V/9/Q تاريخ بذيرش مقاله: 
مىنامند كه معمولاً در كودكى، نوجوانى و به ويزه در دوره

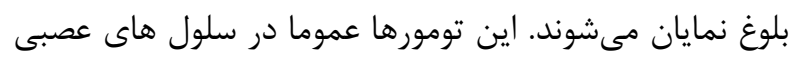
واقع در امتداد اعصاب محيطى و كرانيال ايجاد شده و در در يوست يا زير يوست قابل لمس هستند كه به تدريج بزرت

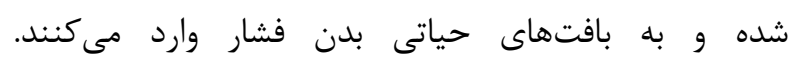

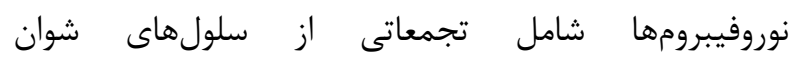

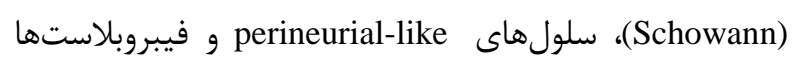
هستند. دو نوع اصلى آن، نوروفيبروماى درمال (dermal) و و

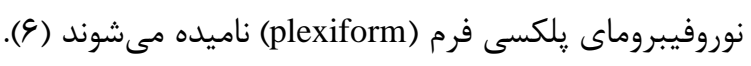
نوروفيبروماى درمال مىتواند هم روى يوست (Cutaneous) و

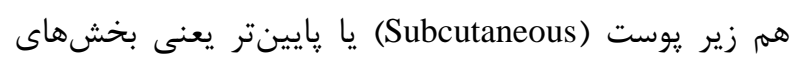

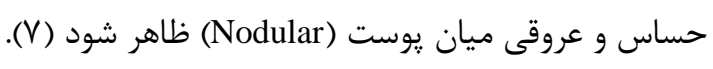

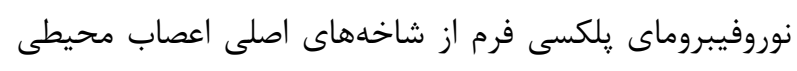

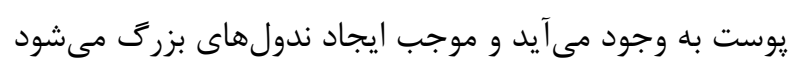

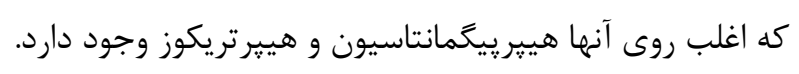
در •و درصد مبتلايان NF1 درون اعصاب محيطى و غلافهاى يوششى اعصاب گسترش مىيابد. از مشخصات نوروفيبروماى يلكسى فرم قابليت تكثير سلول هاى تومورى و در نتيجه

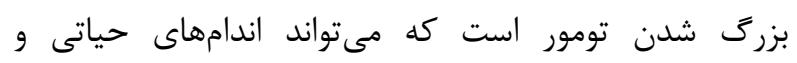

نوع جهشى كه در زن NF1 رخ مىدهد، مىتواند به نحو معنى دارى متفاوت باشد. در برخى بيماران علايم بيمارى بسيار خفيف است و در شمارى ديخر شديد است (ه).

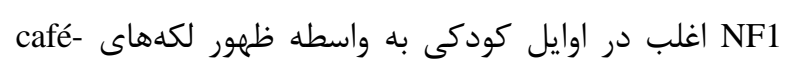
au-late

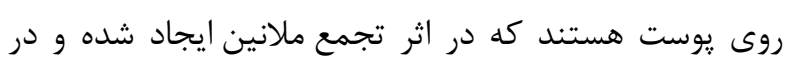

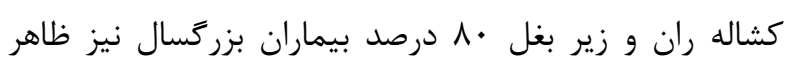

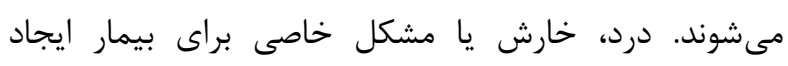
نمى كنند و در هر جايى از بدن ممكن است ديده شوند.

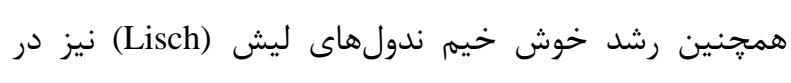

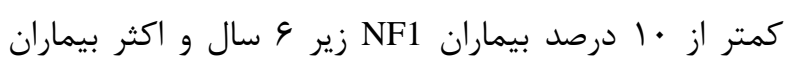

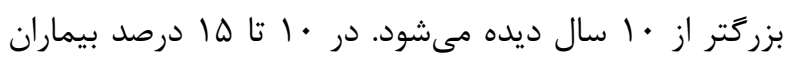

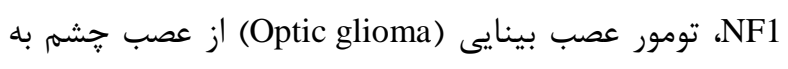
سمت مغز گسترش يافته و به كاهش ديد يا نابينايى منجر

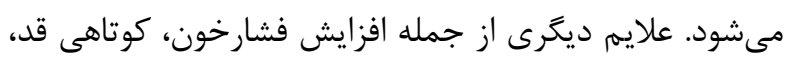

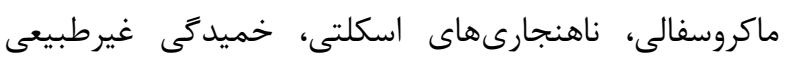

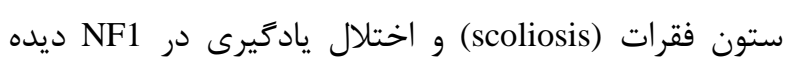

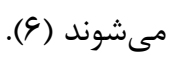
تومورهاى خوش خيم NF1 را نوروفيبروم (Neurofibroma)

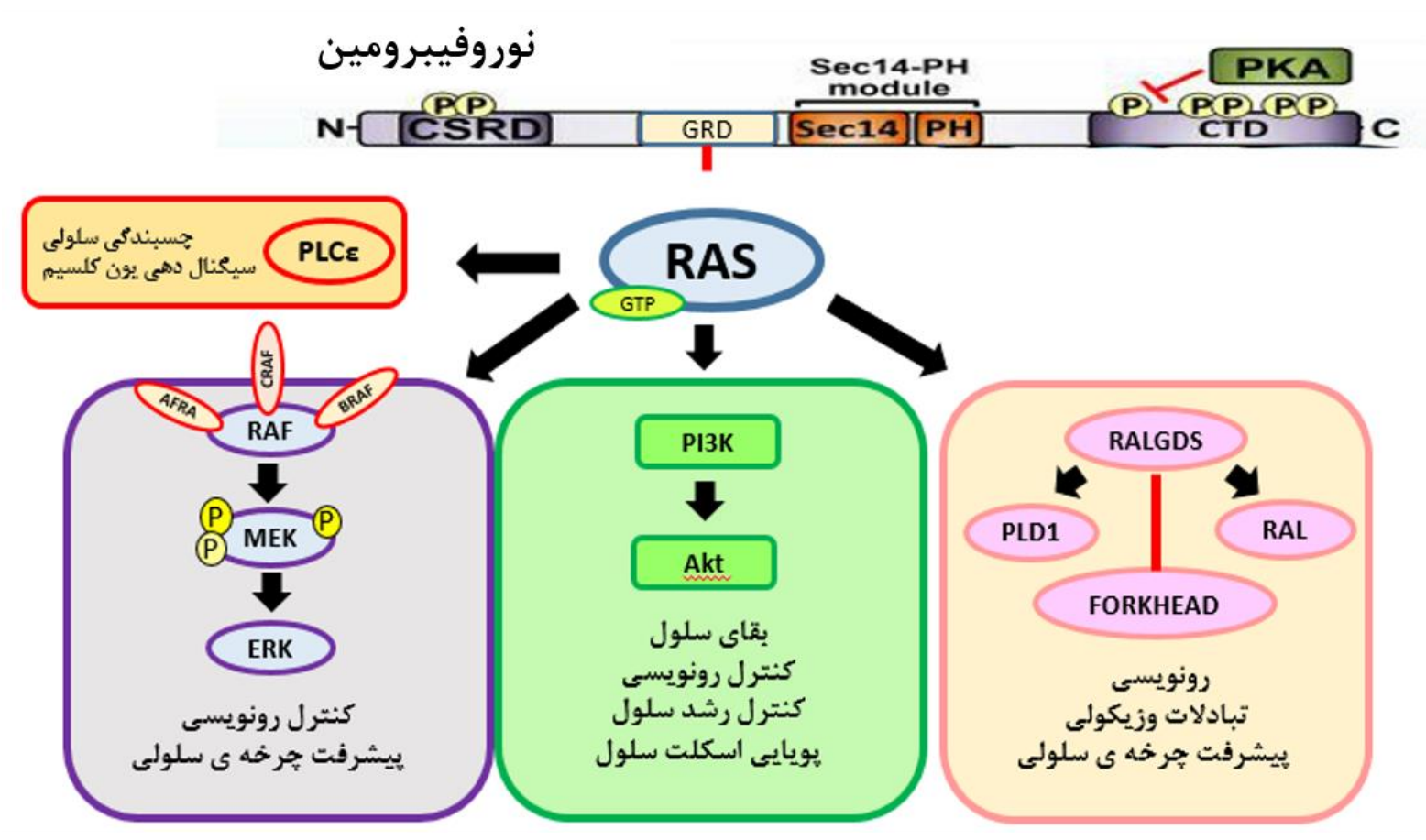

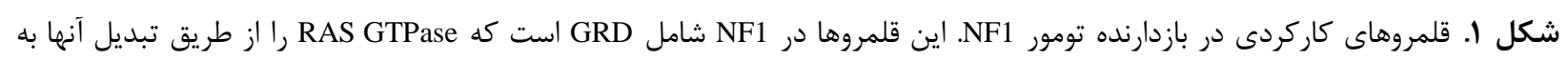

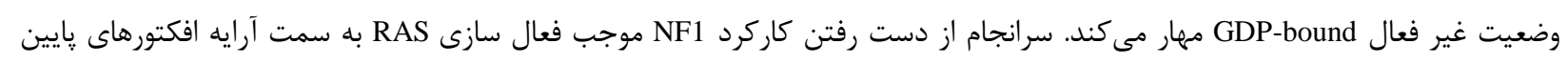

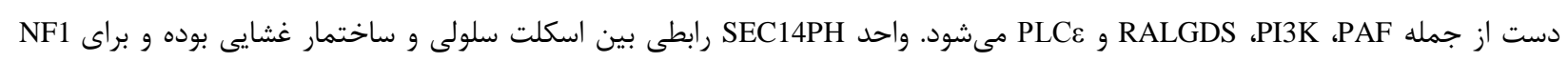

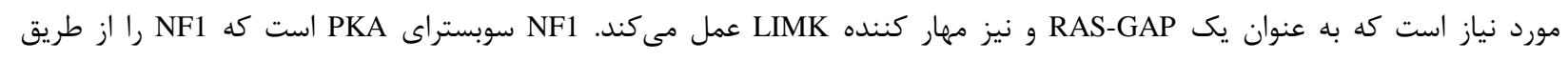

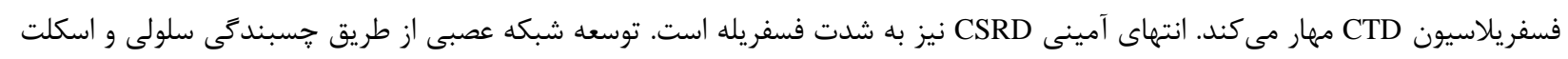




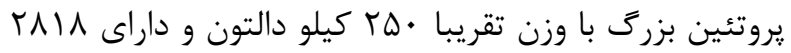

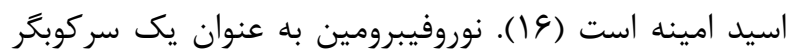
بالادست، نقش تنظيم كنند

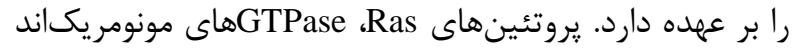

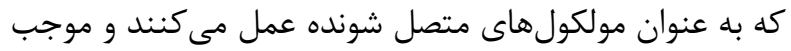

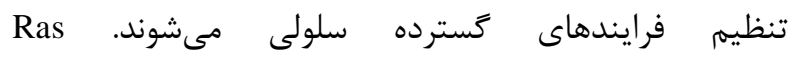
توسط guanine nucleotide exchange factors) GEF (GTPase activating proteins) GAP عاملها سطح فعاليت Ras را بدون تغييرات كوالانسى تنظيم

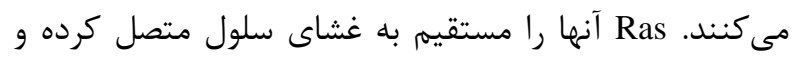
همجنين موجب تنظيم تغييرات مههم پس از ترجمه، از جمله

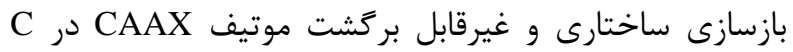

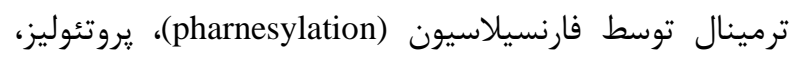

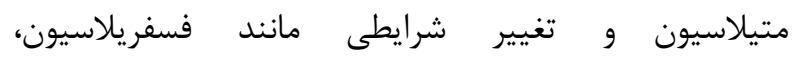

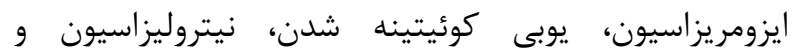

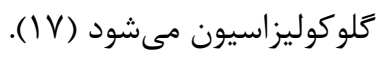
هنكامى كه Ras به GTP متصل مىشوده، به (1V) شكل فعال و زمانى كه به GDP متصل مىشود، به شكل غير فعال خود

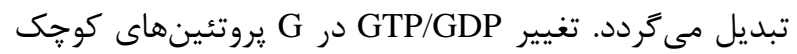

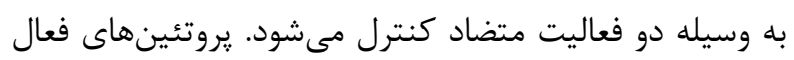

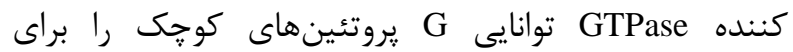

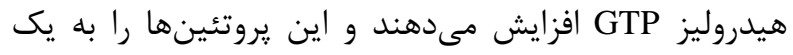

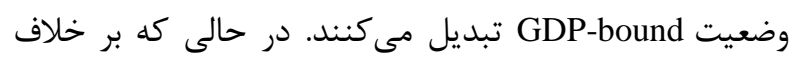
آن، عامل تغيير دهنده نوكلئوتيد توانين (GEFs) آزاد شدن

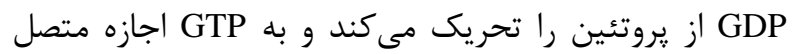

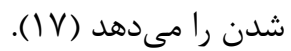

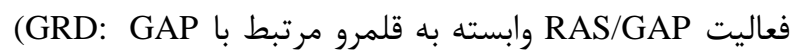
GAP related domain)

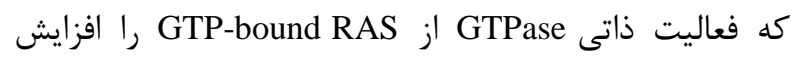

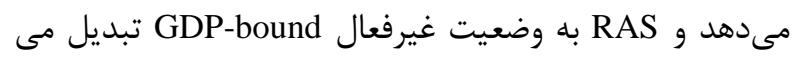
شود. بنابراين جهشهاى نوروفيبرومين به باركيرى GTP و و

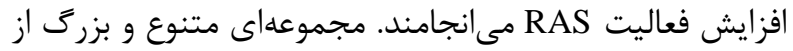

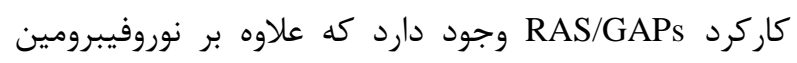
ca ،GAP1IP4BP ، p120GAP يروتئينهاى ديخرى مانند ،ynGAP ،n GAP ،promoted RAS inactivator (CAPRI) g RAS GTPase activating-like protein RASAL 1, DAB2IP افراد مبتلا به NF1، شناسايى كاركرد نوروفيبرومين به عنوان

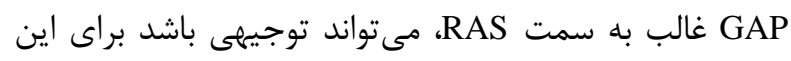

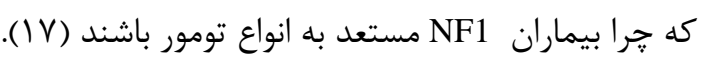

ساختارهاى دست نخورده بدن را تحت تاثير قرار دهد. نوروفيبروماى يلكسى فرم به دليل ايجاد نقصهاى نواى نورولوزيكى دنى

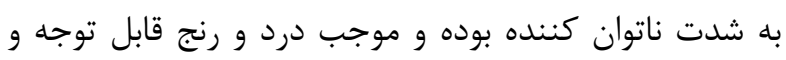
بدشكلى بيماران NF1 مىشود. در اين نوع از نوروفيبروم انجام جراحى جهت برداشتن تومور موجب كاهش بروز مشكلات

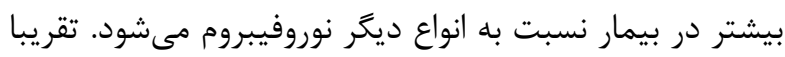

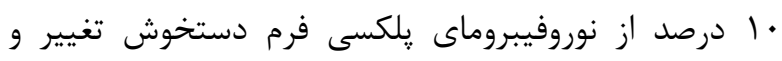

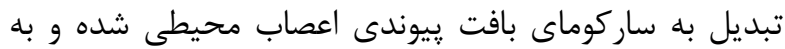
ايجاد تومورهاى بدخيم غلاف اعصاب محيطى (MPNSTs)

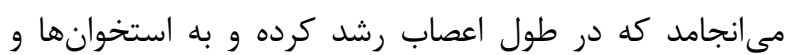

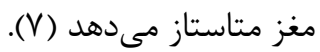

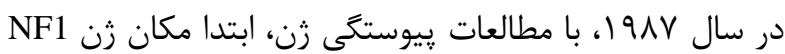

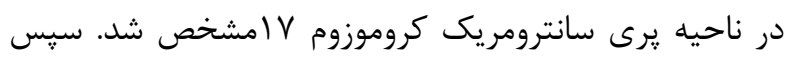

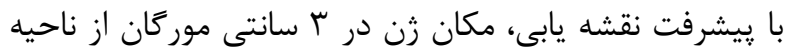

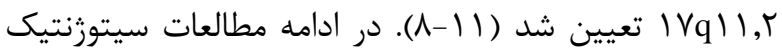

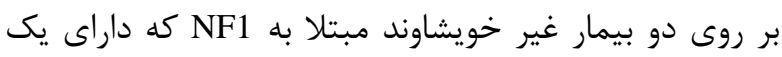
جابجايى متعادل و شكست در مكان زن NF1 بودند، جايكاه زن قطعى تر شد. سرانجام در سال • •199 زن NF1 با تجارب دنادي همسانه سازى موضعى (j) (positional cloning) در ناحيه

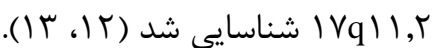

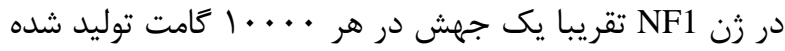

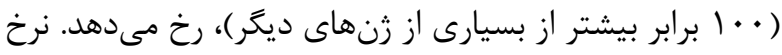

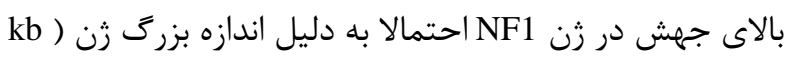

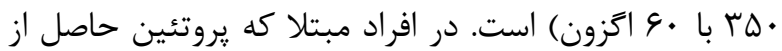

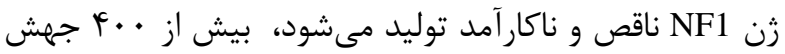

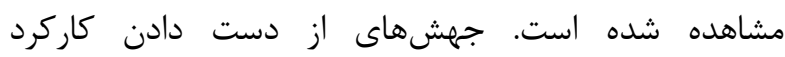

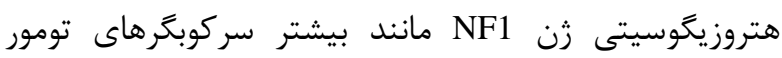
جهش يافته به تومورزايى مى انجامد. در اين بيماران نسبت به به جمعيت عمومى شيوع سرطان بيشتر است و خطر افزايش

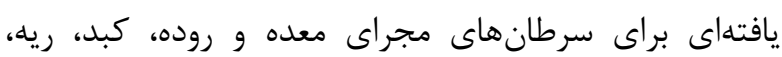

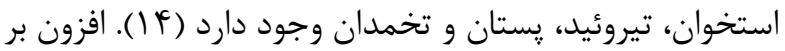
اين، جهشهاى سوماتيك زن NF1 مى تواند در سرطانهان

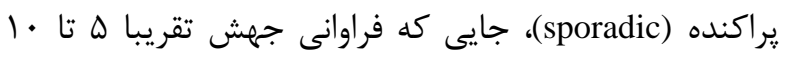
درصد است، رخ دهد (ها) (ب).

\section{زن سركوبكر تومور NF1 و زن انكوزن Ras در سرطان} رن NF1 كدكننده يروتئين نوروفيبرومين است كه به عنوان

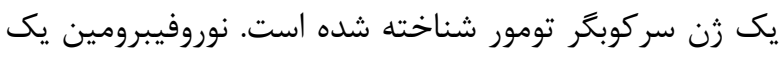


ارتباط قلمرو نوروفيبرومين با تشكيل تومور

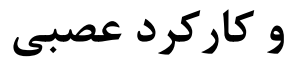

با انجام بررسىهاى كسترده در مورد قلمرو GRD، ديخر قلمروهاى محافظت شده و كمتر شناخته شده نوروفيبرومين هم اهميتدار شدند. قلمروهاى كليدى و و كاركردى pleckstrin homology نوروفيبرومين مشتمل بر Sek14 C-terminal domain (CTD) و هستند كه در كاركرد نوروفيبرومين مشاركت دارند. حضور قلمروهاى هند كاركردى الن الني در نوروفيبرومين ييشنهاد مىدارد كه اين يروتئين به عنوان

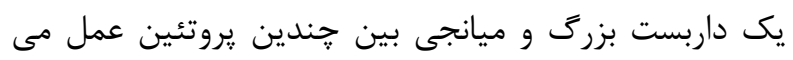
كند تا هماهنگى لازم براى سيخنالهايى كه در كاركرد و ورئ

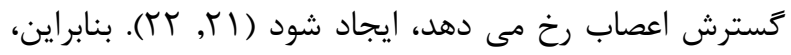

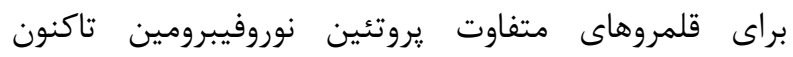
كاركردهاى مهمى به ويزه موارد زير شناخته شده است:

الف)ضرورى بودن قلمروى Sec14-PH از نوروفيبرومين براى سركوب تومور و تنظيم اسكلت سلولى از طريق

LIMK در نواحى مركزى نوروفيبرومين (بالاى قلمرو GRD) حوزه Sستقر است كه متصل شدن نوروفيبرومين به Sec14-PH سطح غشاء و تردد وزيكولها را در سيستم درون غشايى

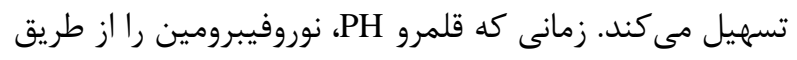
ييوند شدن به لييِد هاى فسفاتيديل اينوزيتول به سطح غشان

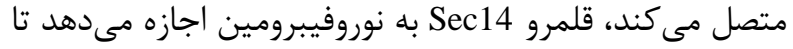

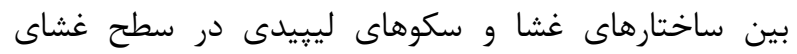

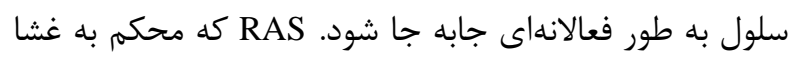
متصل مىشود يك واسطه يرنيلاسيون (Pernylation) است

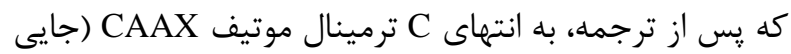

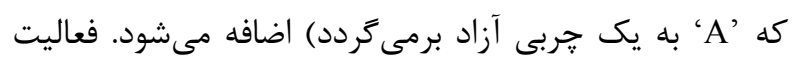

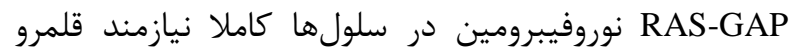
Sec14-PH

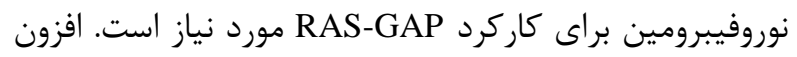

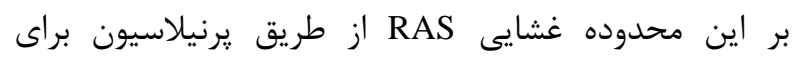
ظرفيت تغيير يذيرى ضرورى است. به منظور تقويت سيخنال

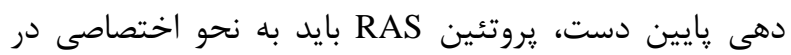
اين محدوده غشايى قرار كيرد (rT).

شيوههاى درمانى بر اساس مهار يرنيلاسيون RAS توسعه

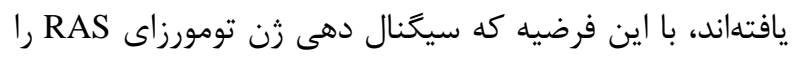

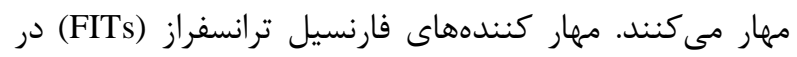
ابتدا به عنوان يك عامل ضد سرطان اميد بخش بود، اما بعدها
يروتئين هاى RasGRF ، SOS و RasGRP از طريق RAS GEF براى تغيير اتصال نوكلئوتيد گوانين به GTP همخى به

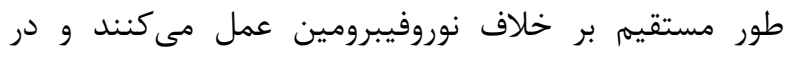

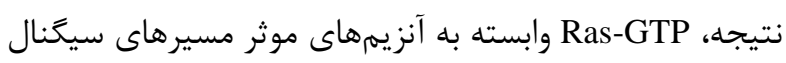
دهى كه در كنترل بقاى سلولى و تكثير سلولى ايفاى نقش

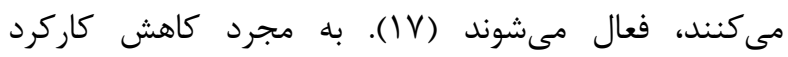
نوروفيبرومين و فعال شدن RAS سطح بالائيى از مشتقدات تكثير شونده، عاملى براى ايجاد توده تومورى بزرى و نامنظمه

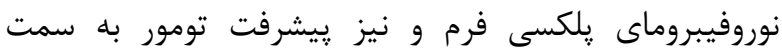

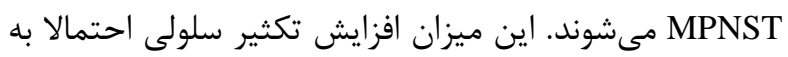

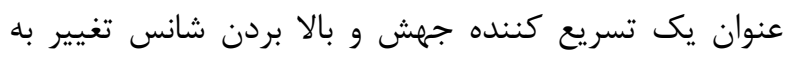
بدخيمى عمل مى كند. افزايش خطر קيشرفت سرطان رودهاى

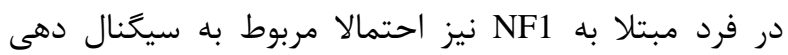

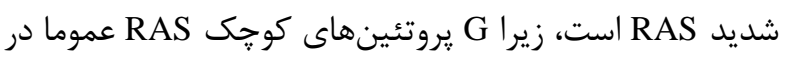
سرطان روده جهش يافته و فعال هستند (1).

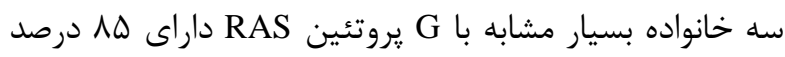

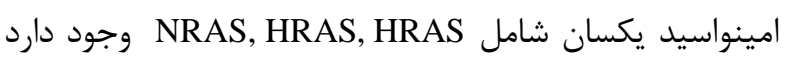

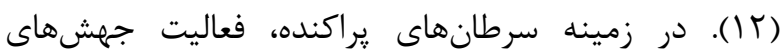
KRAS

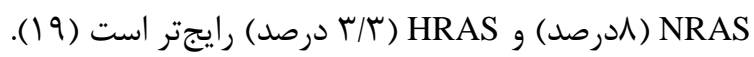

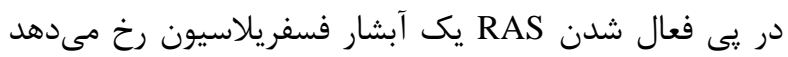
كه موجب فعال شدن سيخنال هاى ميتوزنيك براى كيرندهنهاى

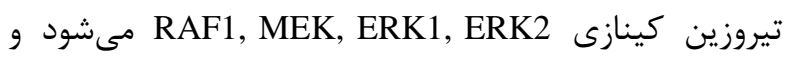
سرانجام به رونويسى از عاملهاى رونوينى ونى و ايجاد طيف وسيعى از پاسخهاى سلولى مانند رشد، تمايز، التهاب و آيويتوز منجر مىشود (· (T).

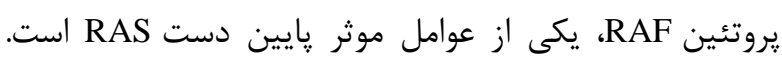

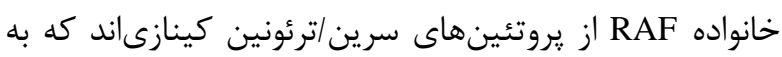
ناحيه موثرى از RAS-GTP متصل شده و در نتيجه موجب القاى انتقال يروتئين به غشاى إز يلاسمايى مىشوند. ميان

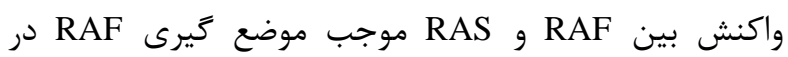
غشاى يلاسمايى مىشود. اين امر در حالى است كه برائ

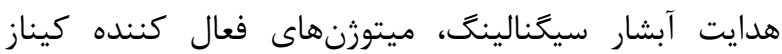

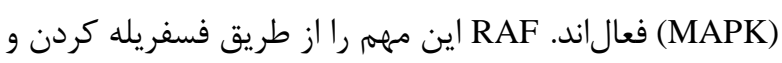
فعال كردن MEK (ميتوزن فعال كننده يروتئين كيناز) انجام مىدهد كه در بى فسفريله شدن و فعال شدن (ERK 1/2) extera cellular signal-regulated kinase1/2 مسير קيام دهى MAPK (شكل ()، ERK1/2 فعال شده و سيس به سمت هسته جا به جا مىشود تا يك برنامه رونويسى (شيى

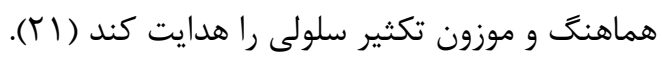


و همكارانش نشان دادند كه ناك داون يا غير فعال Ozawa شدن نوروفيبرومين به فشردىى بيش از حد فيبرهاى اكتين منجر مىشود و در نتيجه مسير بيام دهى RHO در domain kinase 2 (LIMK2) (افزون بر LIMK1) سوبستراى يروتئين كيناز ايجاد كننده ييجش مرتبط با RHO است كه در يايين دست افكتور RHO قرار دارد. يس از آن كه سازوكار اكتين براى نخستين بار ازئ

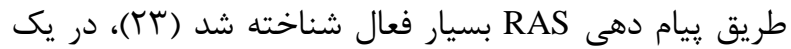
مطالعه جديدتر فعل و انفعال بين نوروفيبرومين و LIMK2 نشان داده شد. سازماندهى دوباره اسكلت سلولى براى بيشتر فرايندهاى سلولى مانند جنبش سلولى، جسبندكى سلولى، سيتوكينز و به ويزه افزايش التهاب عصبى مههم است. LIMK2 يك سرين/ترئونين دو واحدى و تيروزين بروتئين كيناز دخيل

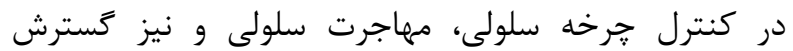
ياختهاى عصبى است (YU-YV). در زمينه بيمارى NF1، فعاليت LIMK2 افزايش يافته و به
مشخص شد كه يرنيلاسيون RAS منحصر به تغييرات پֶ از ترجمه نيست، بلكه مىتواند توسط زرانيل زرانيل ترانسفراز

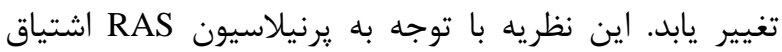

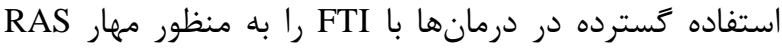
كاهش داده است. فعاليت ضد تومورى FTIs احتمالا از طريق مهار ديخر GTPase هاى يرنيله شده، انجام مى گيرد. يك نامزد بالقوه GTPase، (RAS homology enriched in brain) Rheb است، كه بر خلاف RAS منحصرا از طريق فارنسيل ترانسفراز، يرنيله مىشود. FTIs مىتواند به مقدار كافى سيخنالهاى

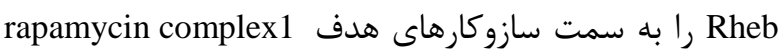
مسدود كند كه براى هدايت رشد سلول و ركزايى (Mtorc1) شناخته شده است. Rheb/GTPase فعاليت آنكوزنيك دارد و يك فعال كننده يروگسيمال Rheb براى آيويتوز

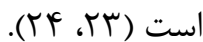
جهش غير وابسته به فارنسيلاسيون در Rheb موجب مىشود

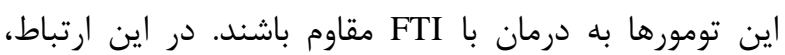

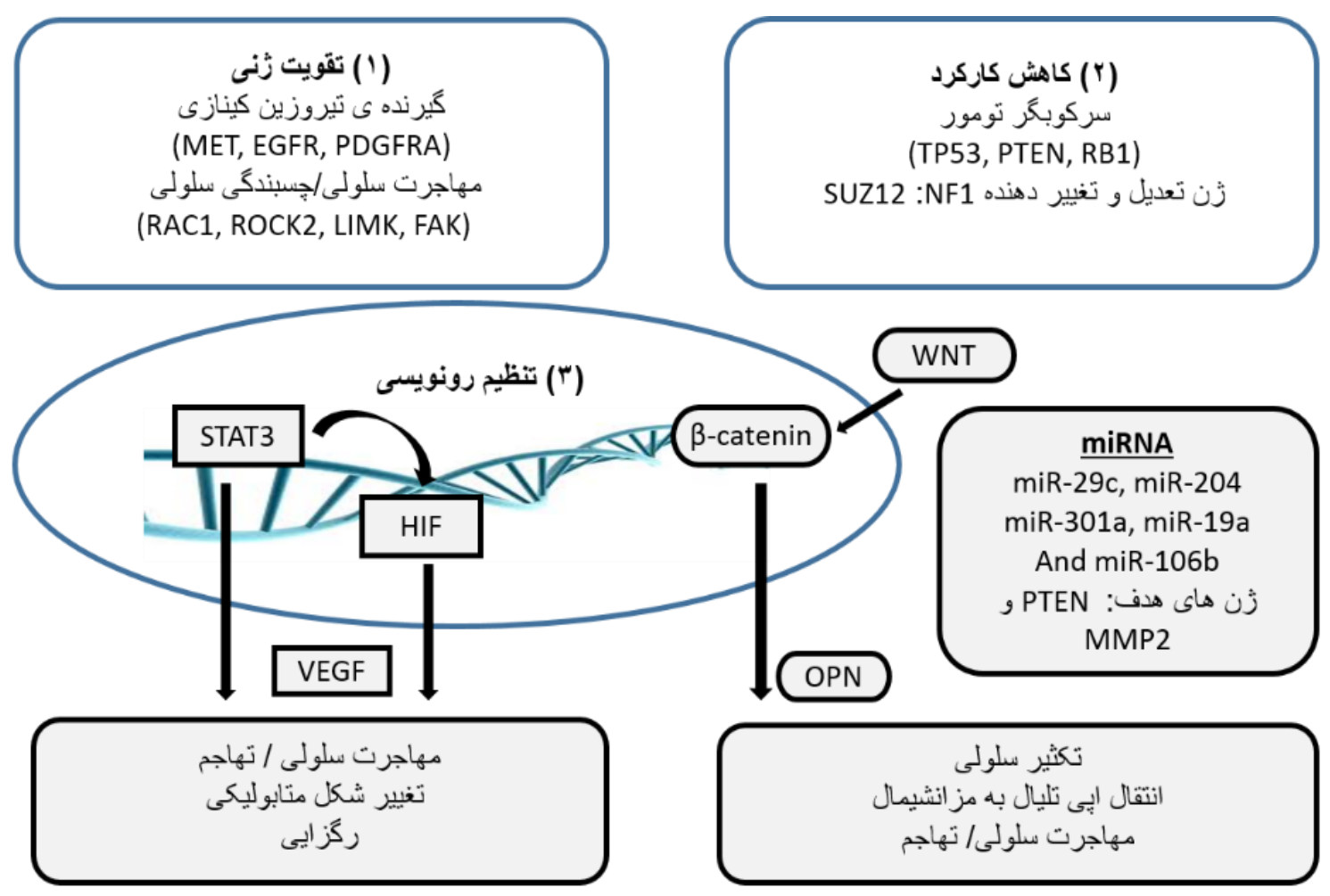

شكل r. بيشرفت سرطان MPNST. خلاصهاى از رويدادهاى زنتيك مولكولى ييشرفت نوروفيبرماى خوش خيم به سمت MPNST:

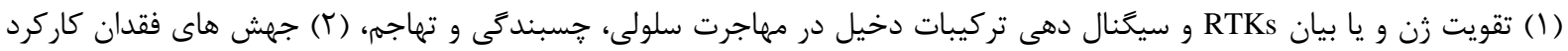

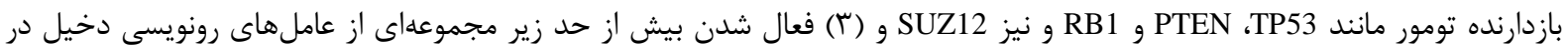

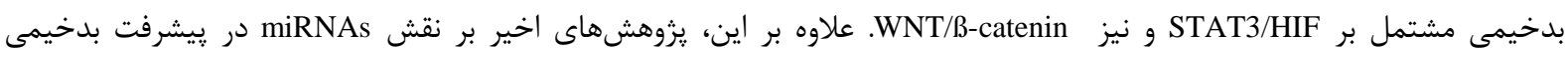


قلمرو C ترمينال، مجموعه اى از زروتئين كينازهاى وابسته به Ser2576, 2578, 2580, Thr2556 از جمله (PKA) CAMP شناسايى شدهاند كه از فعاليت نوروفيبرومين RAS-GAP

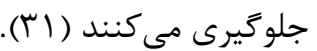

(CRMP2) Collapsin response mediatorprotein2 ديخر از واكنش دهندههاى نوروفيبرومين است كه به قلمرو C ترمينال متصل مىشود. CRMP2 در تغيير وضعيت دادن وهندي اسكلت سلولى دخيل است كه اين امر براى قطبيت ياختههاى عصبى و هماهنگَى در جهت گيرى مناسب آكسون لازم است.

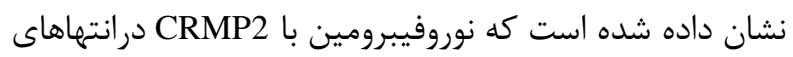
ديستال و انشعابات گسترش يافته از ياختههاى عصبى موضع ندان كيرى مى كند. اتصال نوروفيبرومين و سركوب CRMP2، مانع

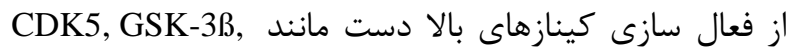
ROCK1

\section{NF1 مر تبط با MPNST}

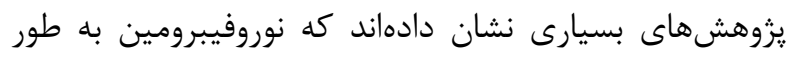
حتم در ايجاد نورون ها مشاركت داشته و از طريق بسيارى از برديان قلمروهاى كاركردى عمل مى كند. غير فعال شدن دو آلل NF1 آل

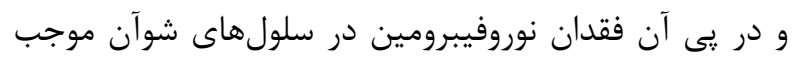
فعاليت دراز مدت Ras شده و در نتيجه افزايش تكثير سلولى ندان

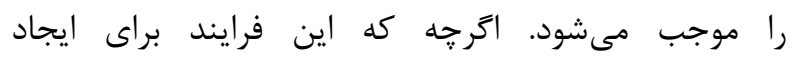
نوروفيبروماى خوش خيه كافى است، اما شمارى رويدادهاد إنهاى زنتيكى هم هستند كه در نوروفيبروما ايجاد بدخيمى كافى مى كنيند.

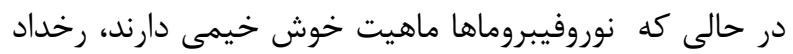

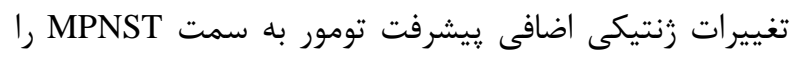

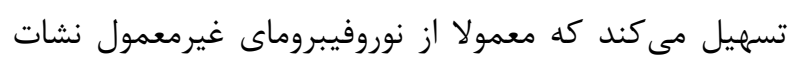

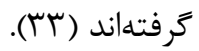

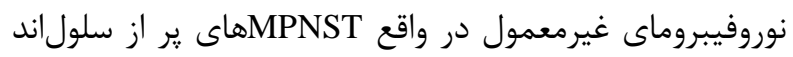

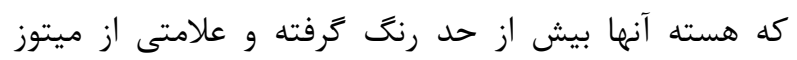
ندارند (سب). فقدان كاركرد NF1 به افزايش تكثير منجر شده

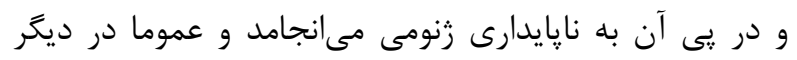

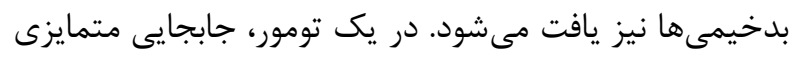

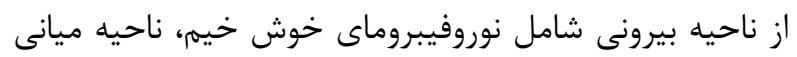

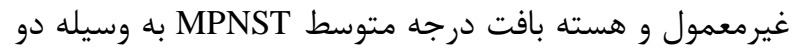

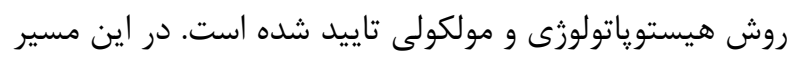

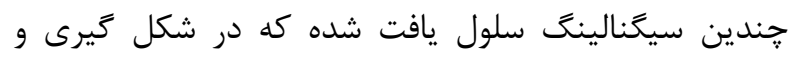
ايجاد ساب كوتائوس (subcutaneous) و ييشرفت MPNST ايفاى نقش مىكنند (شكل r). مسيرهاى كيرنده تيروزين
بازسازى اكتين اسكلتى منجر مىشود. LIMK2 اين كار را از

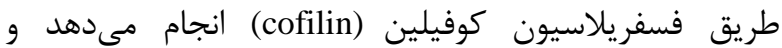
كوفيلين فعال كه مسبب ديليمريزاسيون اكتين است، مهار شده و در نتيجه ساختار اكتين طويل مىشود. همجنين مشخص شده است كه نوروفيبرومين به عنوان يك تنظيم كننده منفى مسير RAC1/PAK1/LIMK1/cofilin مستقل

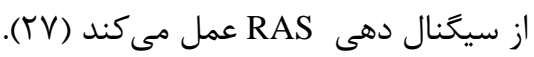
ب) كاركرد نوروفيبرومين به عنوان يك يروتئين دار داربسني FAK1 Fنظيم كننده ايجاد سيستم عصبى از طريق اتصال

CRMP-2 و

نوروفيبرومين علاوه بر مشاركت در بازآرايى اكتين، بال

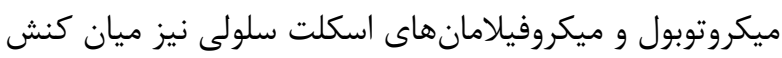

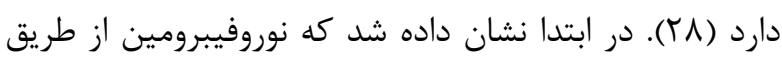

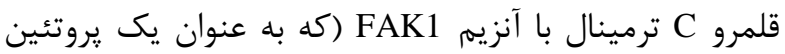

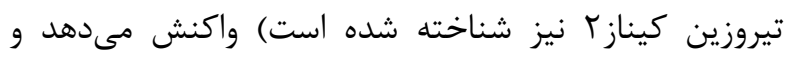

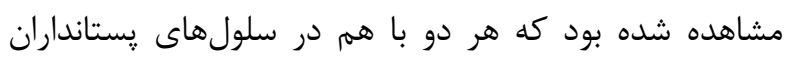

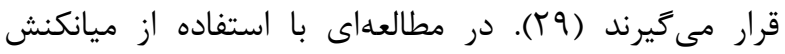

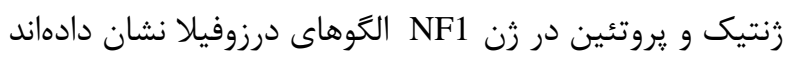

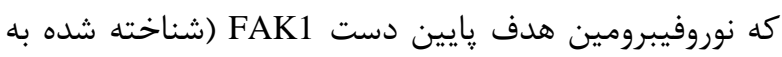
عنوان FAK56 در درزوفيلا) است، جايى كه FAK1 با نواحى دئ دائ

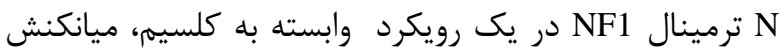

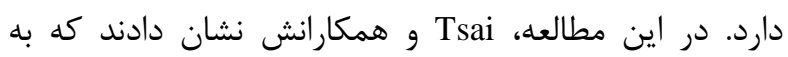
مجرد كاهش NF1، ارسال سينايتيك افزايش مى ميابد. اين رخداد نشان دهنده آن است كه NF1 براى كاركرد طبيعى

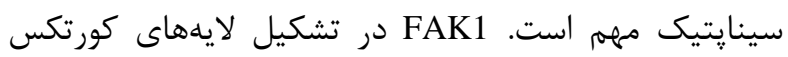

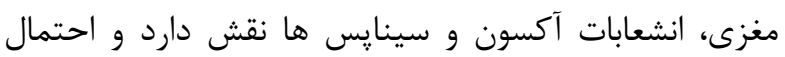
مىرود كه ميانكنش بين NF1 با FAK1 براى ايجاد شبكه

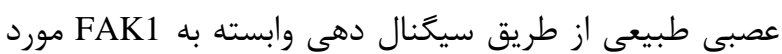

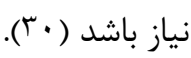
در مطالعه ديخرى نشان داده شد كه FAK1 مى تواند هم به N N ترمينال و هم به C ترمينال نوروفيبرومين متصل شود. دليل

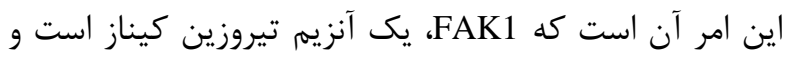

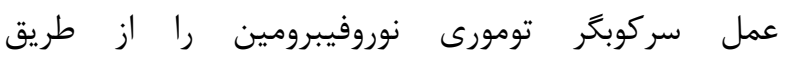
فسفريلاسيون مستقيم تنظيم مى كند. مطالعاتى يِيرامون فسفريلاسيون نوروفيبرومين توسط كيناز بالادست و سيخنال -

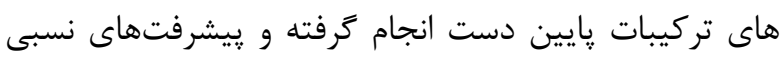

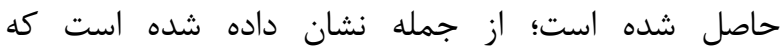
نوروفيبرومين در قلمرو غنى از سرين/ سيستئينين (CSRD) و

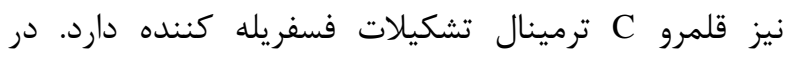


متاستاز ديده مىشود. سرانجام، جالشهاى بالينى براى درمان MPNST با هدف درمانى يك دارو يا تركيبى از داروها

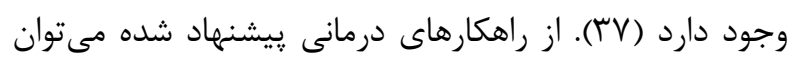
به موارد زير اشاره كرد:

(1) تقويت كيرنده تيروزين كينازها در MPNST آناليز از دست دادن هتروزيخوسيتى (LOH: Loss Of نشان داده است كه مظنونان هميشكى Heterozygocity) سرطان يعنى زنهاى ان P53(Tumour Protein P53) PTEN(Phosphatase , RB1(Retinoblastoma protein 1)، and tensin homolog) در طى بررسىهاى جزئى و دقيق پيشرفت بدخيمى از

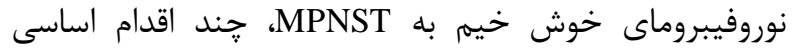

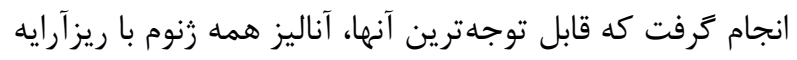

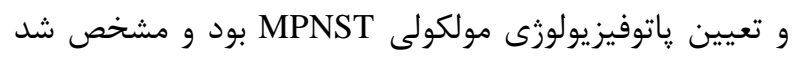

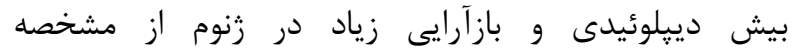

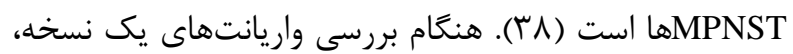
جندين كيرنده كيناز (RTKs) در تومورهاى بدخيم در مقايسه

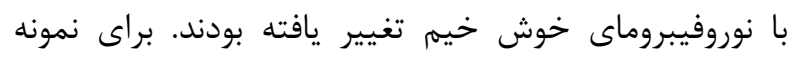

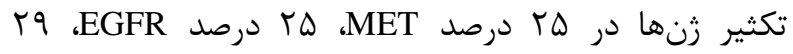

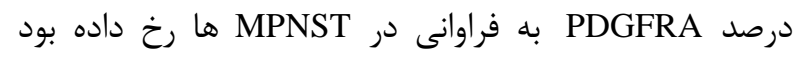

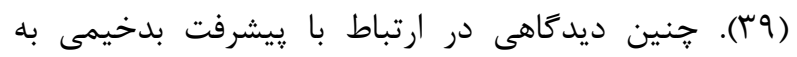

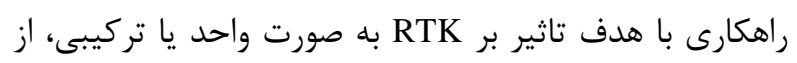

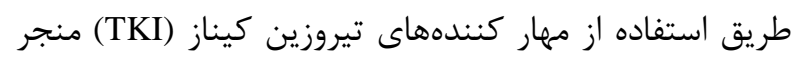

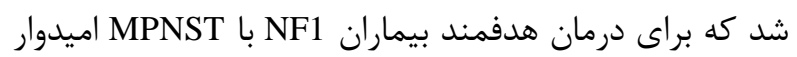

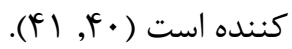

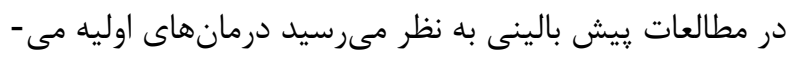

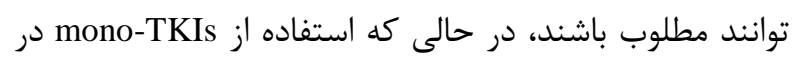

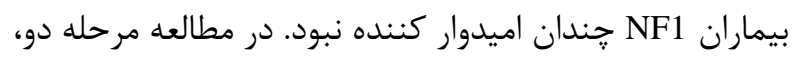
استفاده از ايماتينيب (Imatinib) و يك مهار كننده تيروزين

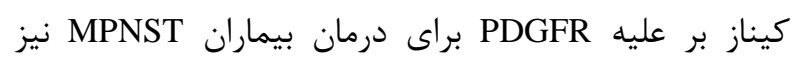

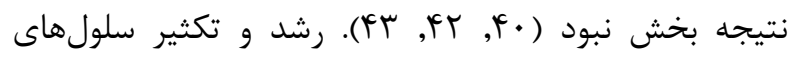

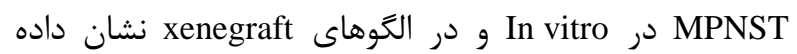
است كه سه رده از شش رده سلولى MPNST كه مورد آزمون

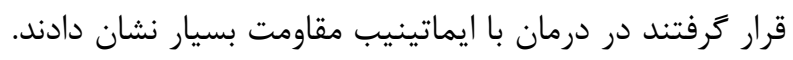

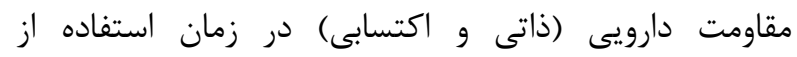

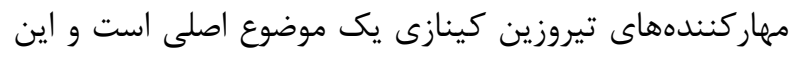

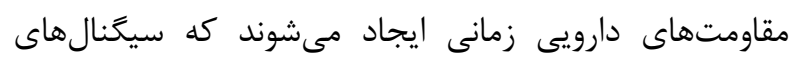

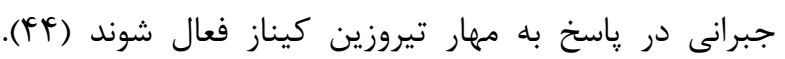

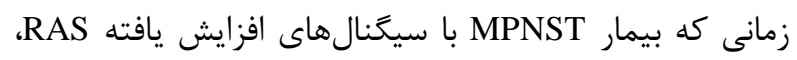
ياسخهاى بالينى قابل توجهى به يك مهار كننده
كيناز و كَيرندهاى عامل رشد به نامهاى MAPK و

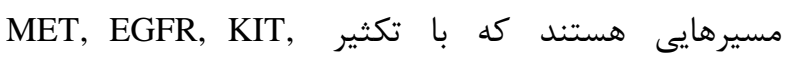
PDGFRA مىشوند و تعداد نسخهاى تنظيم كنندهاى مهرم جرخه سلولى مانند CDKN1C, CDKN2A/B/C, MDM2, TP53 تغيير مىكنند. در مطالعهاى كه با استفاده از كاريوتايي، NF1 روى Ma microarray انجام كرفت، در طى بررسى و مقايسه بين Copy ) CNP (Number Polymorphism

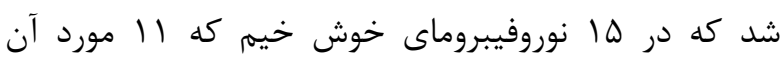

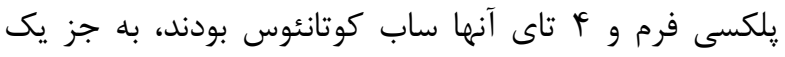

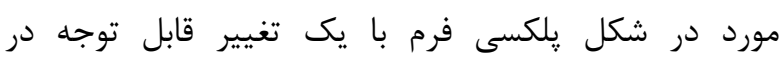

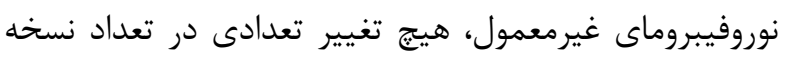

هاى آنها مشاهده نشد (TY) (T).

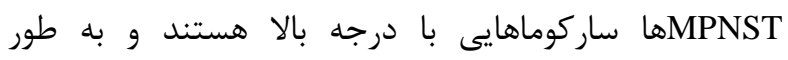

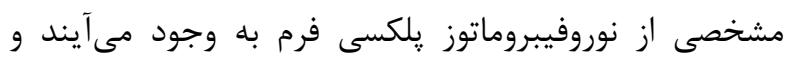

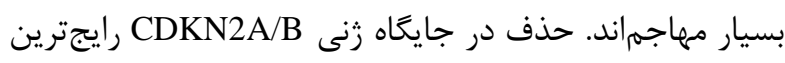

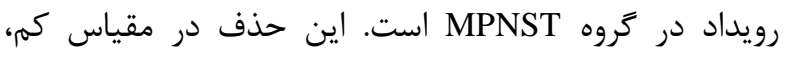

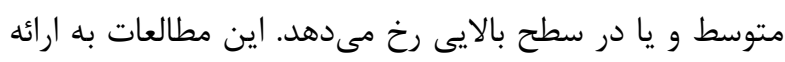

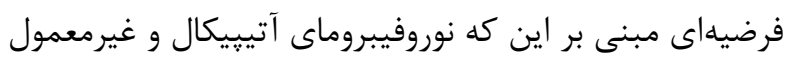

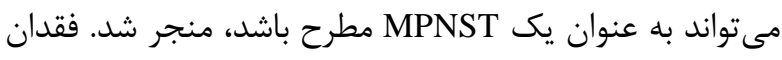

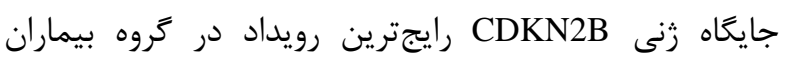

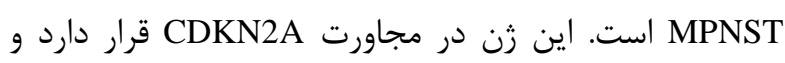

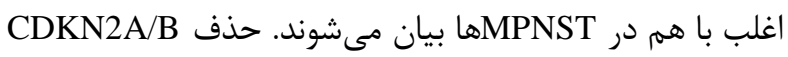

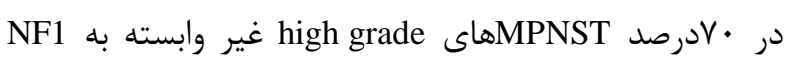

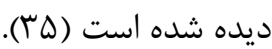

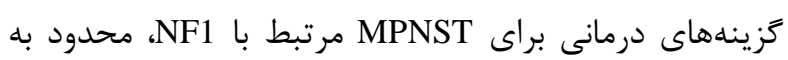

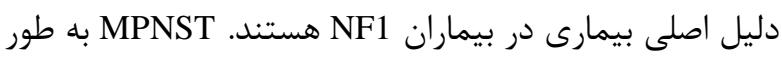

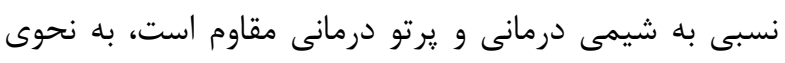

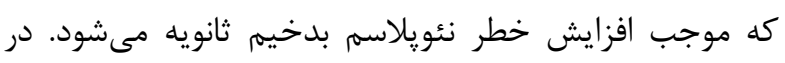

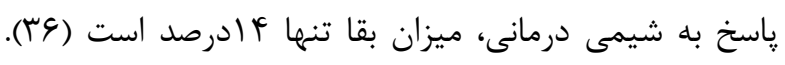
درمان اصلى MPNST حذف كامل تومور با حاشيه آشكار

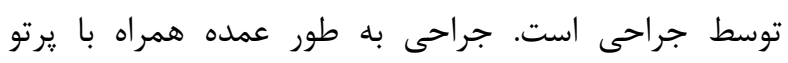

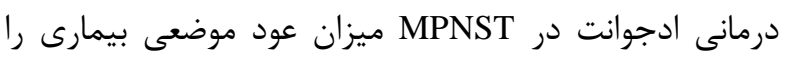

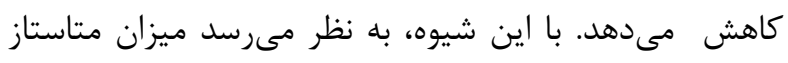

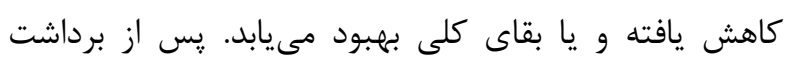

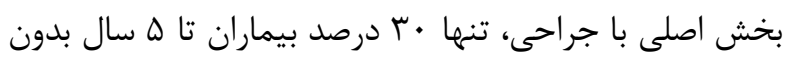

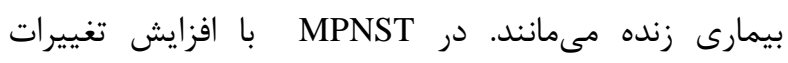

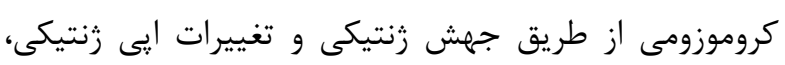

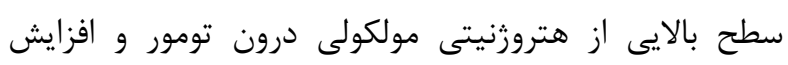


كننده هييوكسى (HIF) و VEGFA عمل مي كند. مولكول

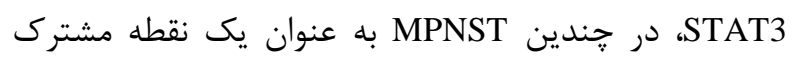

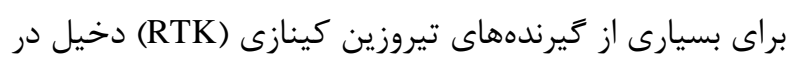

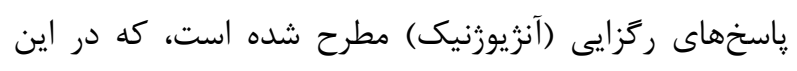

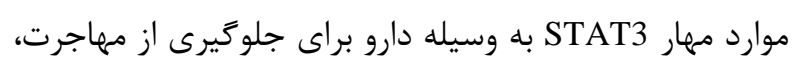

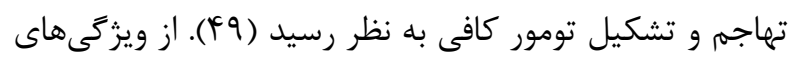

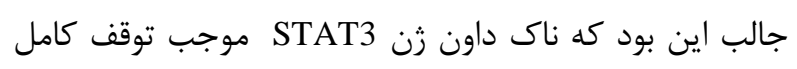
در بيان HIF-1

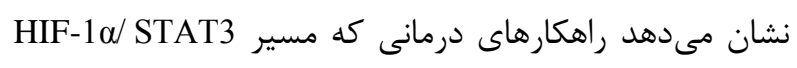

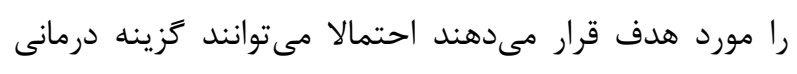

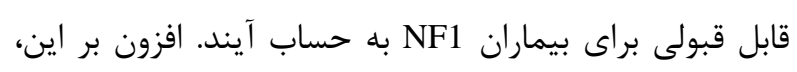

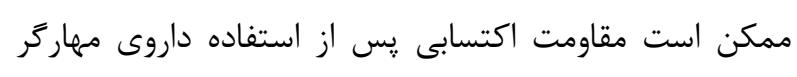

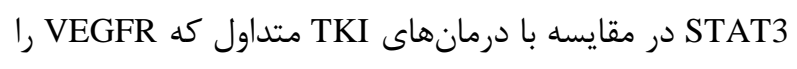

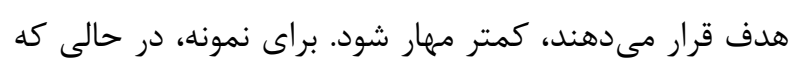

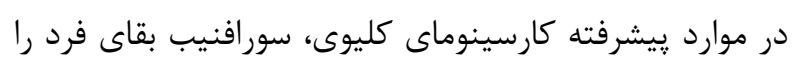

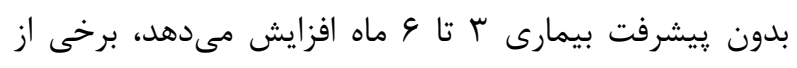

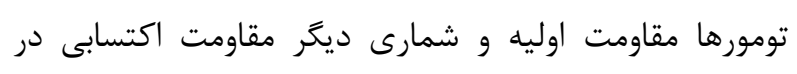

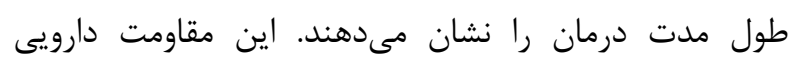

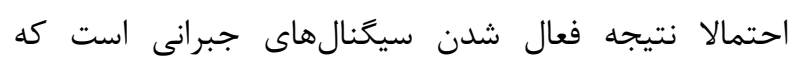

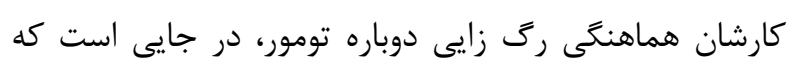

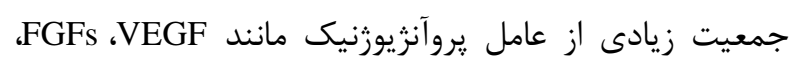

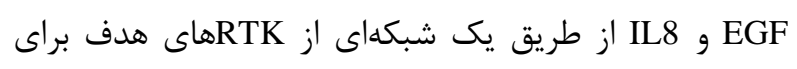

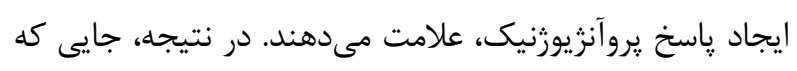

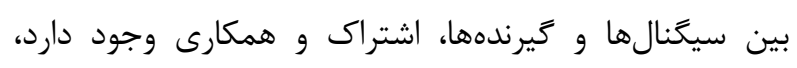

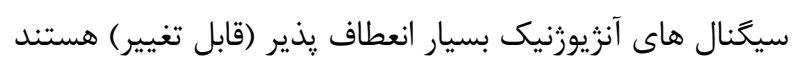

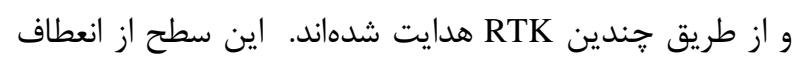

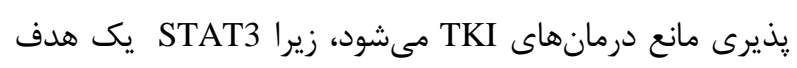

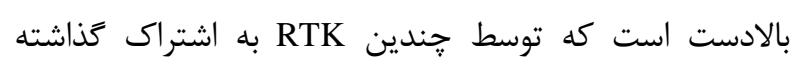

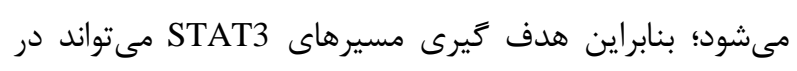

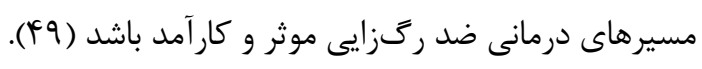

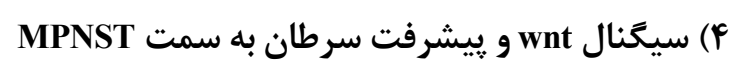

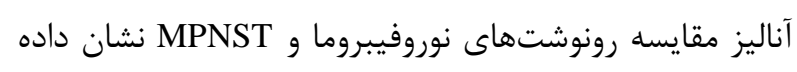

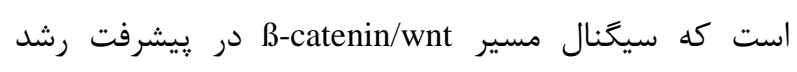

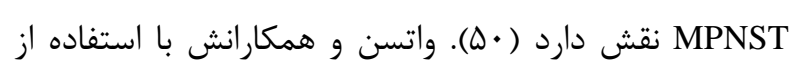

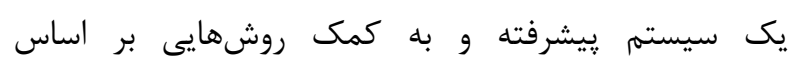

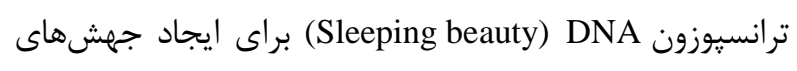

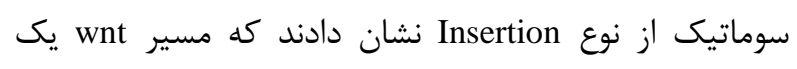

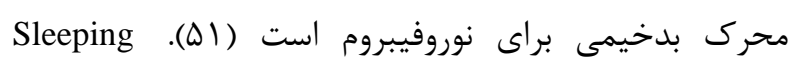
beauty و سركوبكرهاى تومور دخيل در بدخيمى هاست، تا جايى كه
مانند Sorafenib (كه Nexavar هم ناميده مى شود) مى دهد،

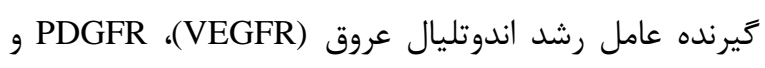

Raf kinases

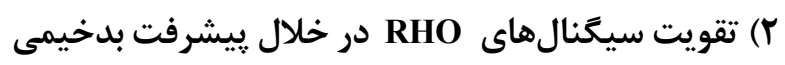
جنان جه كه يِيش تر اشاره شد، نوروفيبرومين در سازماندهى

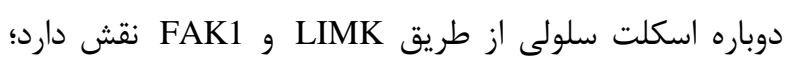
بنابراين اختلالات بيشتر در اسكلت سلولى موجب يُ بيشرفت

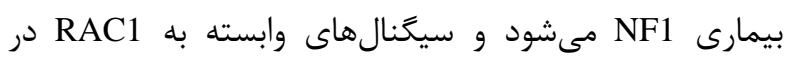

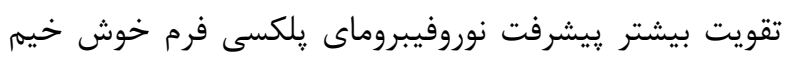

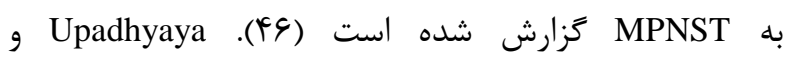

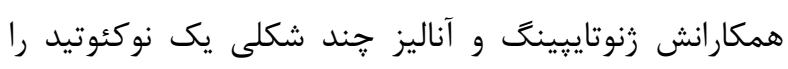

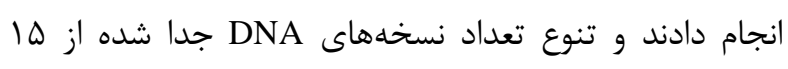

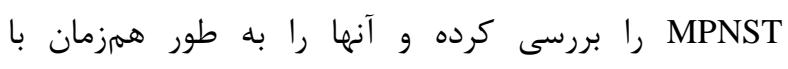

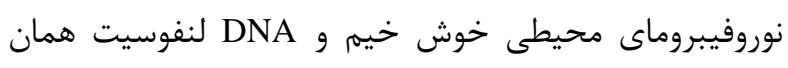

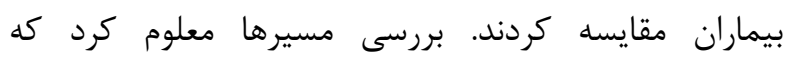

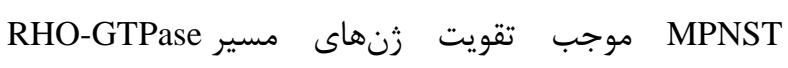
و نيز زن هاى بازسازى اسكلت سلولى و من ماير (RAC1, ROCK2)

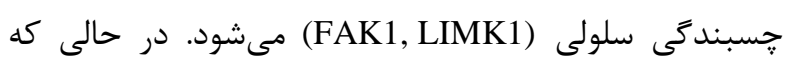

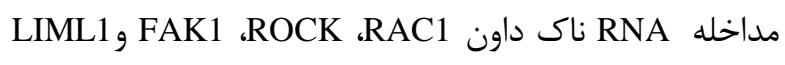

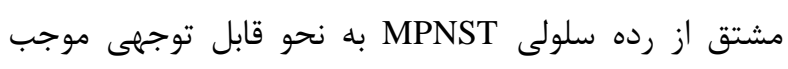

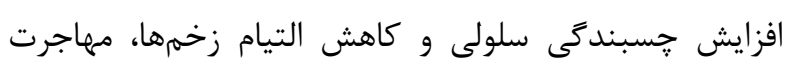

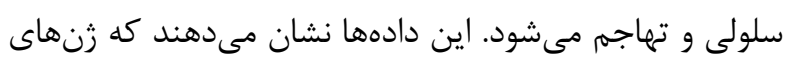

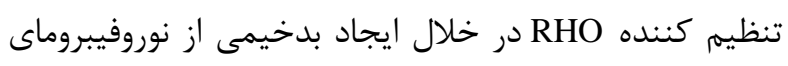

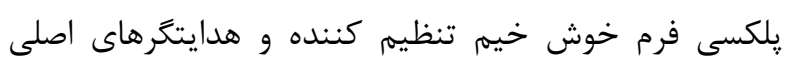

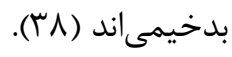

\section{r)سيخنالهاى آنثيوزنيك در MPNST و M مشاركت}

STAT3

نفوذ طبيعى MPNST و موفقيت درمانكرهاى آنتى آنزيوزنيك

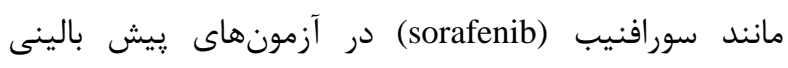

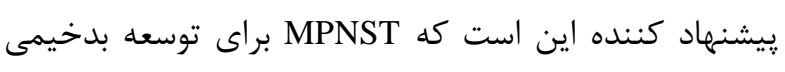

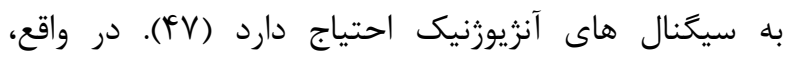
Gesundheit

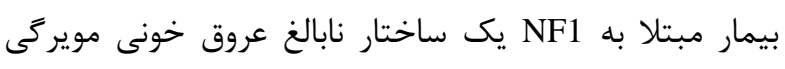
دارند كه يادآور جوانه ركزايى (sprouting angiogenesis) است و نكته مهم اين است كه اين عروق خونى مشاهده شده

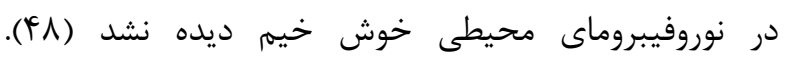

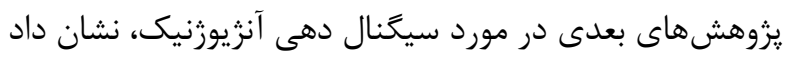
كه مبدل سيخنال و فعال كنندههاى رونويسى دودى ( STAT3)

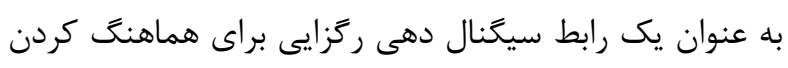

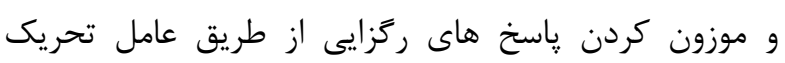


در تعدادى از تومورهاى انسانى از جمله سرطان روده PRC2

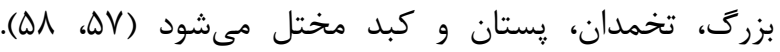

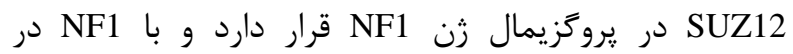
سركوب كردن رشد تومور همكارى مى كند. در واقع، بيشترين

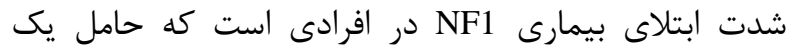

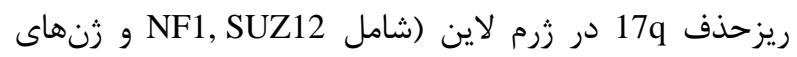

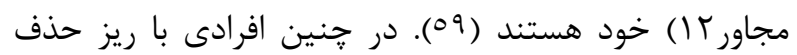
17q شيوع بالايى از تومورهاى خوش خيم و بدخيم وجود دارد كه نشان دهنده همكارى كاركردى بين NF1 و در واقع جدا كردن SUZ12 موجب افزايش رشدكلونى تومئ دماري

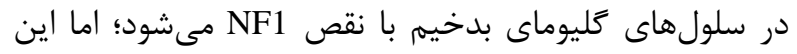

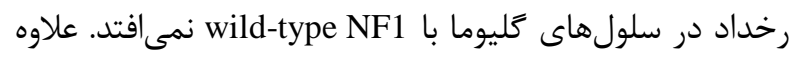

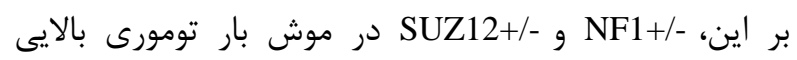

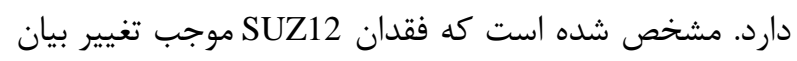
زن از طريق كاهش ترى متيلاسيون H3K27 و افزايش

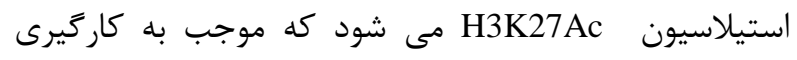

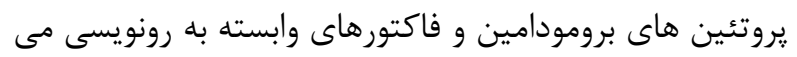
كردد. De Readt و همكاران نشان دادند، مسدود كردن اين

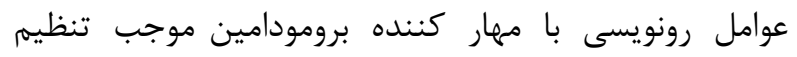
وضعيت ايى زنتيكى سلول هاى فاقد SUZ12 و و كاهش سايز موني

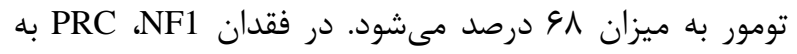

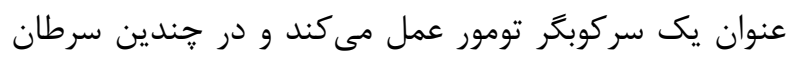

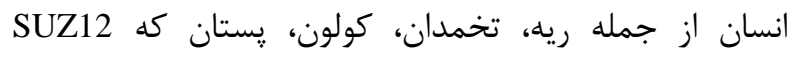
تنظيم كننده مثبت است، PRC2 به عنوان يك آنكون آنكوزن عمل

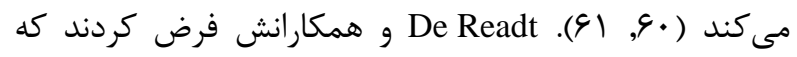

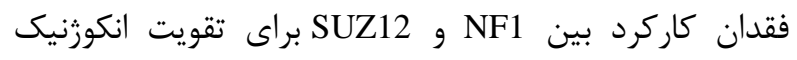
سيخنالهاى RAS و هدايت به سمت بدخيمى ضرورى است

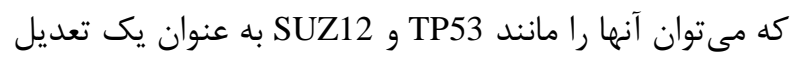

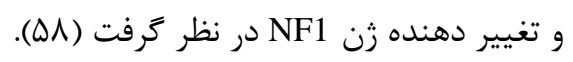

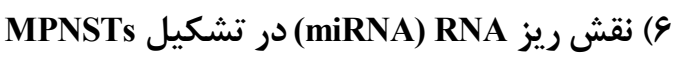
كا ها نوعى از RNARA كاركرد و بيان زنها نقش دارند.

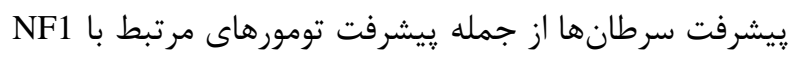
دارند و به طور كلى 9 هو زن از

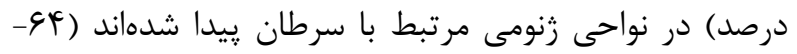

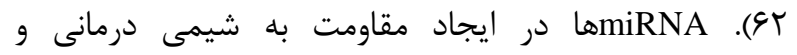

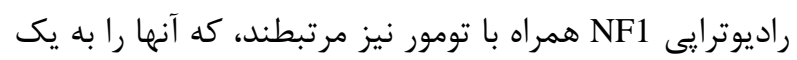
بيوماركر جالب و يك هدف درمانى براى سرطان انهاى ير يراكنده تبديل كرده است. اكرجه نقش miRNA در كسترش تومور هنوز در حد يك تعريف است، اما مطالعات نشان دادهاند
الحاق ترانسيوزون DNA مى Dتواند بيان خارجوب توالىهاى

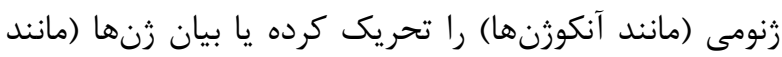

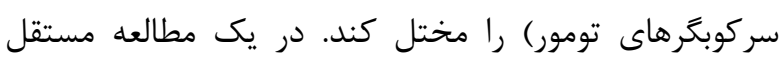
نشان داده شده است كه در وخيمترين حالت MPNST ها در

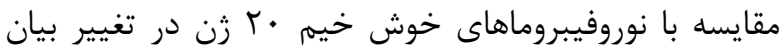

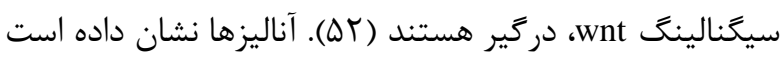

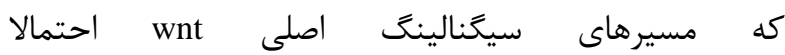
گسترش MPNST را تحريك مى كند (צ\&). در اين زمينه از

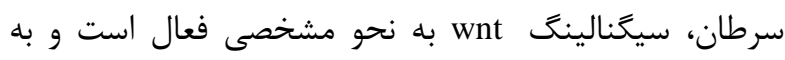

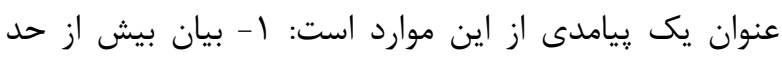

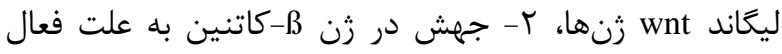

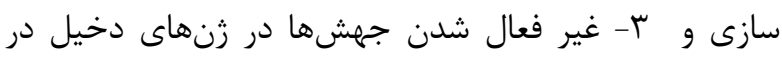

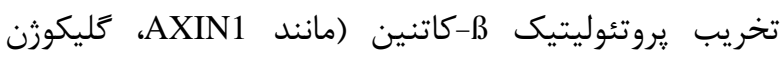

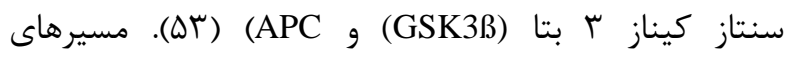

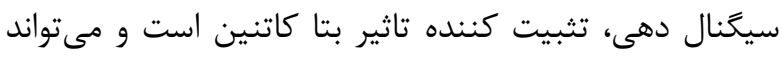

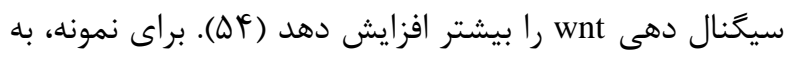
نظر مىرسد فسفريله شدن ATK و غير فعال شدن GSK3B از علل קايدارى بتا-كاتنين هستند (QD).

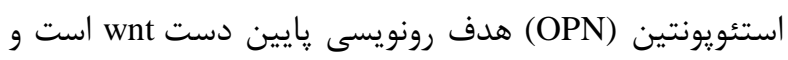

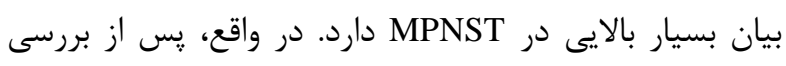
تغييرات نسخه عددى و بيان زن تومورهاى خوش خيم و

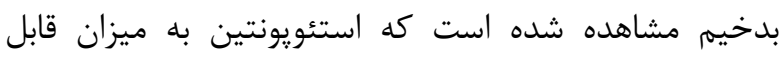

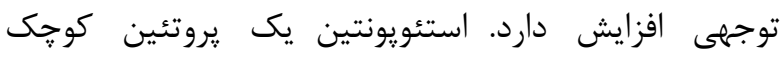
فسفريله است كه به ماتريكس برون سلولى ترشح و باريا

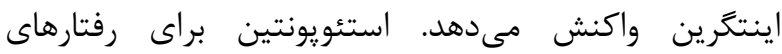

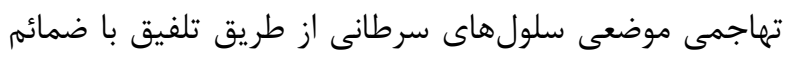

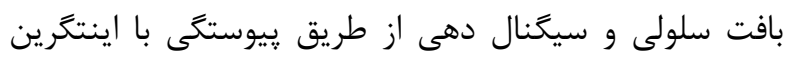

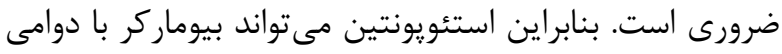

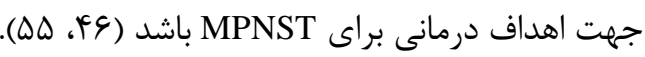

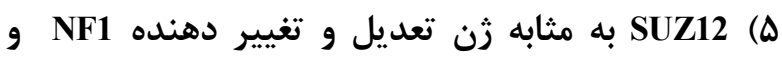
هدايتخر بدخيمى نه بررسىهاى مسيرهاى نامنظم MPNST موجب ييشرفتهاى عمدهاى در اين زمينه شده است. يكى از اين دستاوردها كشف ميف

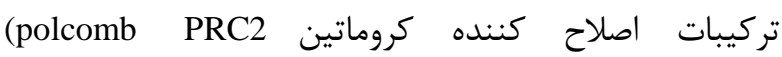
SUZ12، repressive complex2) مكرر از طريق جهشهاى MPNST غير فعال مىشوند (هS).

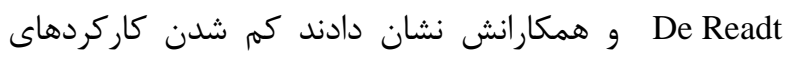

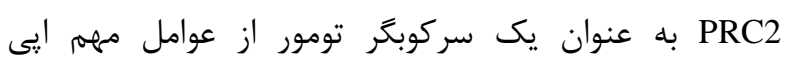
رنتيكى در برنامه ريزى دوباره است و مىتواند به تغيير شكل نوروفيبروماهاى يلكسى فرم به بدخيمى منجر گرددد. تنظيم 
هايى باشد كه موجب افزايش ترجمه از ORFNA

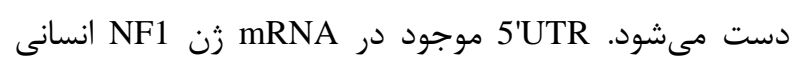
شامل دها است. اين يرسش كه آيا فناورىهاى ويرايش

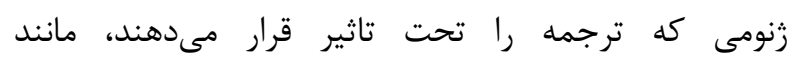
CRISPR/Cas9

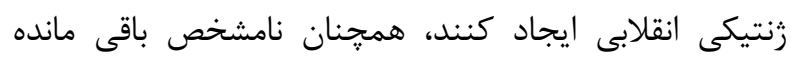

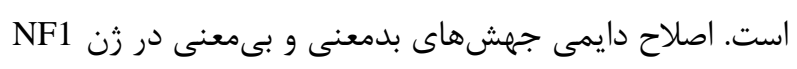

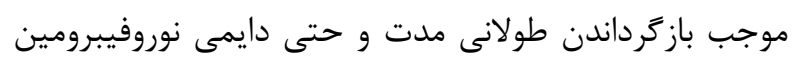

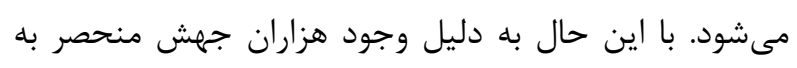

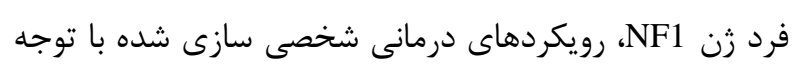

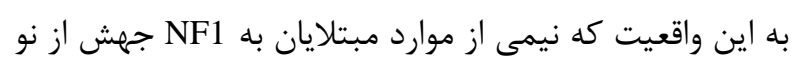

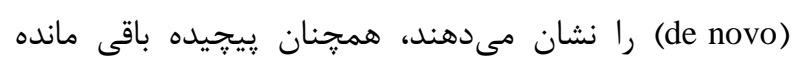

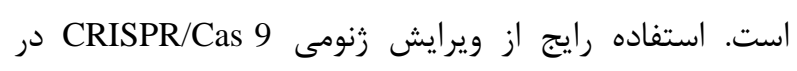

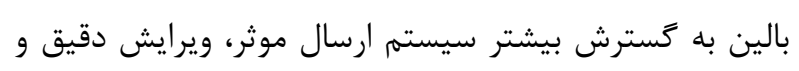

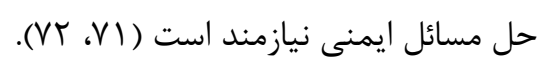

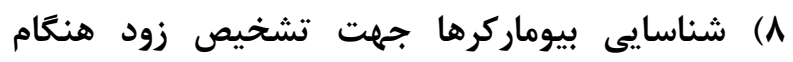
MPNST با كسترش آزمايشهايى براى شناسايى بيوماركرهاى MPNST،

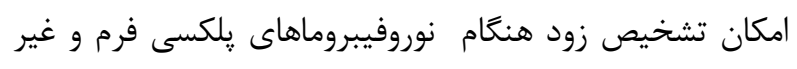

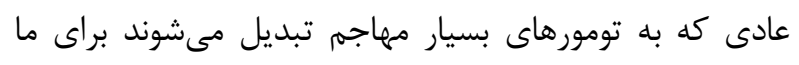

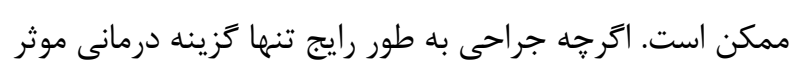

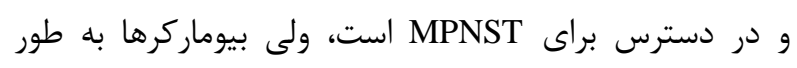
بالقوه مىتوانند در تركيب با تكنولوزىهاى ارسال ثن سن سبب كنترل و مرى تومورهاى بدخيم شوند. استفاده از كتابخانهاى CRISPR ممكن است براى شناسايى حساسيت

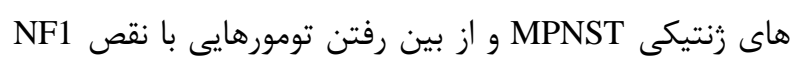
مفيد باشند. طول تلومر ممكن است واجد نقشى دائى در ايجاد

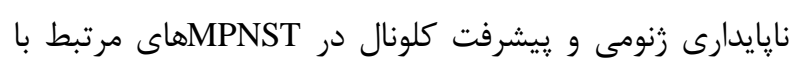

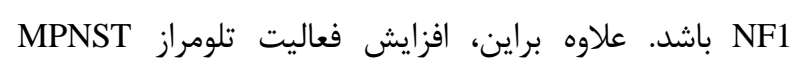

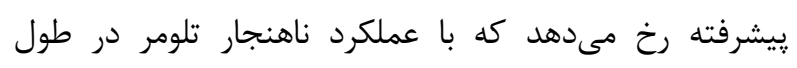

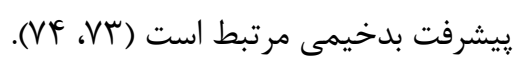

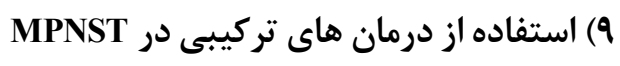

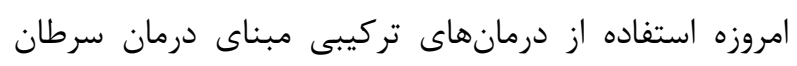

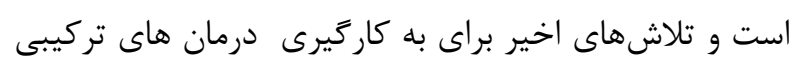

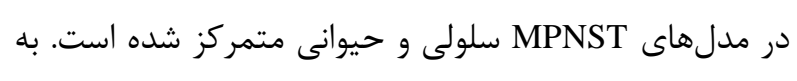
عنوان مثال، افزايش استرس يروتئوتوكسيك با استفاده از مهار

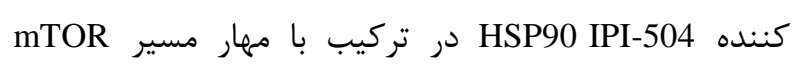

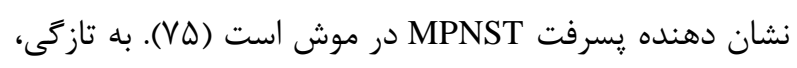
استفاده تركيبى از مهاركنندههاى MTOR و افزايش استرس اكسيداتيو و يسرفت MPNT مورد استفاده

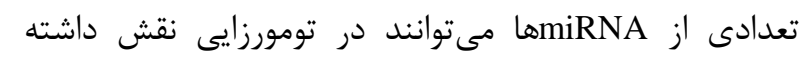

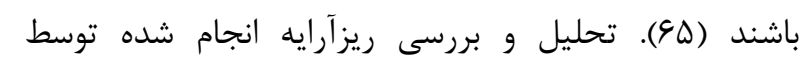
Presneau تنظيم كننده منفى MiRNA در بيماران MPNST در مران مقايسه

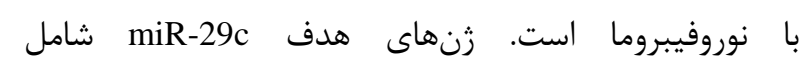
متالويروتئينهاى ماتريكس ب (MMP-2) است كه در تهاجم و و

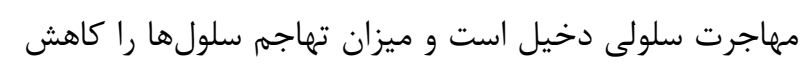

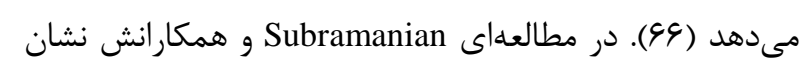

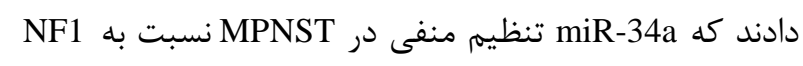

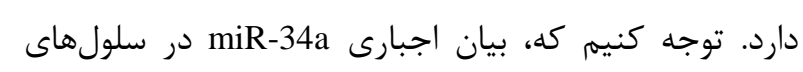

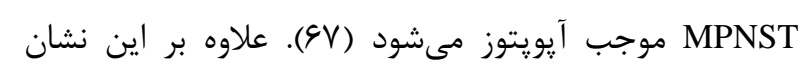

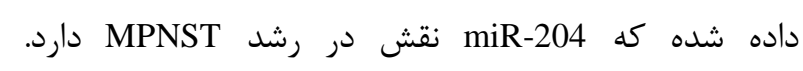

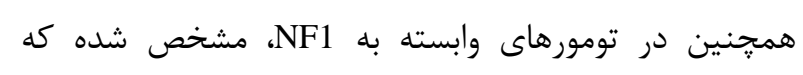

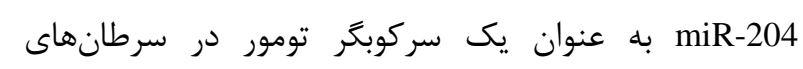

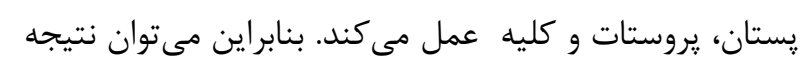

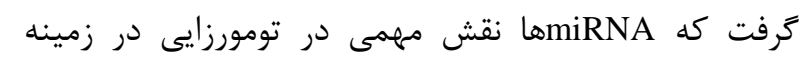

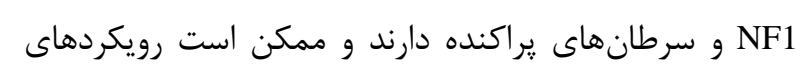

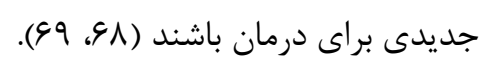

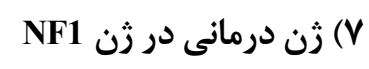

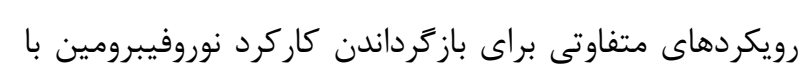

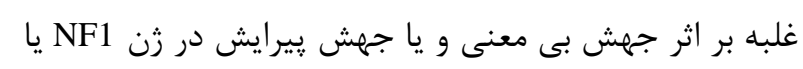

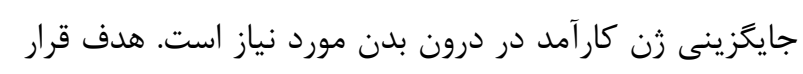

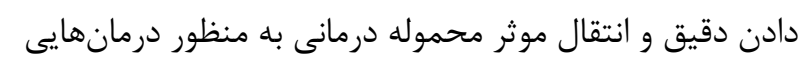

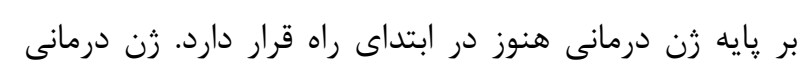

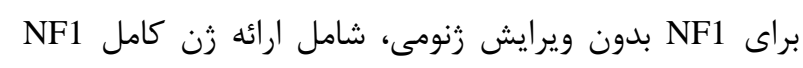

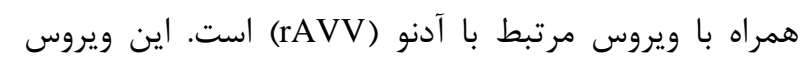

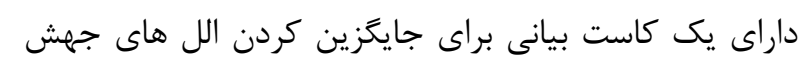

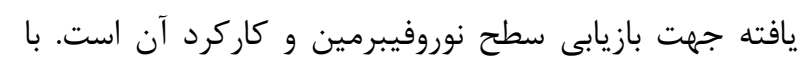

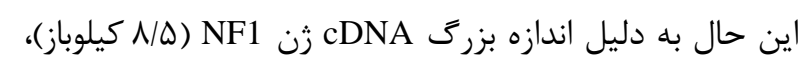

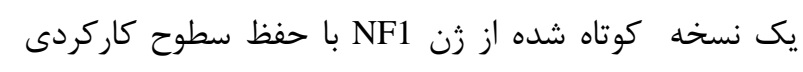

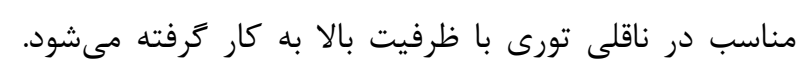
براى فعال سازى زن NF1 و بهبود علائم ايجاد شده ناشى از

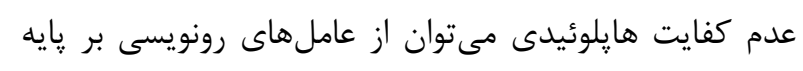

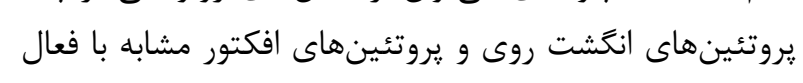

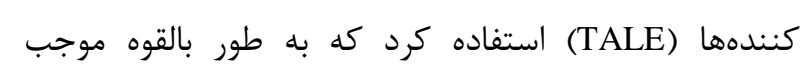

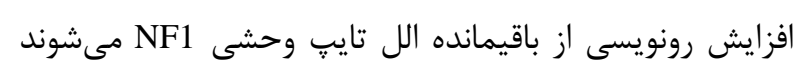

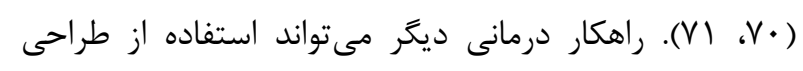

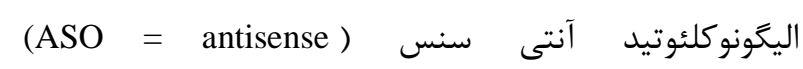

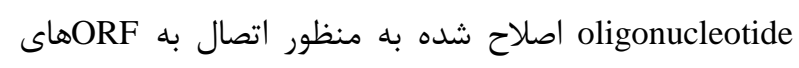

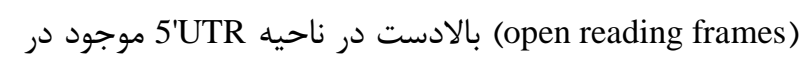


نوروفيبرومين به عنوان RAS GAP شناخته شده، شواهدى دال بر اين است كه نوروفيبرومين يك يروتئين جند كاركردى است. نوروفيبرومين از طريق ارتباط با اسكلت سلولى و ساختار غشايى به عنوان يك يروتئين داربستى عمل كرده، همجنين سيگنالهاى دخيل در رشد و تكثير سلولى، جسبندگى و مهاجرت سلولى را مخابره و به اين ترتيب موجب تكامل

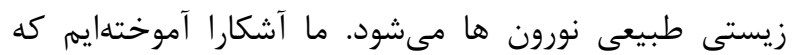
فرايند ييجيدهاى در بسيارى از مسيرهاى سيگنال دهى مرتبط با سرطان موجب مىشود نوروفيبروما به سمت MPNST

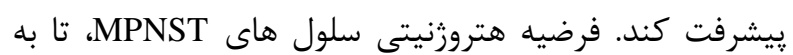
امروز درمان را ناموفق كرده است. با اين حال، ييشرفتهاى اخير درمانى از جمله ويرايش زنوم و ايمونوترايى هدفمند، روشهاى شخصى براى درمان NF1 ران ارائه ميىدهند. يا فناورى ويرايش رن ممكن است به طور CRISPR / Cas9 بالقوه براى تغيير زنوم بيماران NF1 مورد استفاده قرار گيرد. در

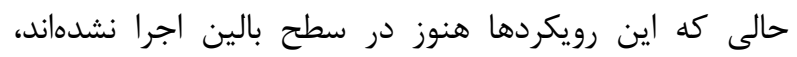

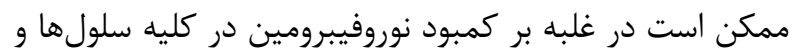
بافتهاى فرد، به ويزه در مبتلايان به جهشهاى de novo، غير عملى باشد. ايمنى درمانى هدفمند به تدريج درمان سرطان ران بان تغيير داده است. تلاش براى شناسايى يروتئين ايمونولوزيك لمانى تومورهاى NF1 ممكن است يك گزينه درمانى براى استفاده از اين رويكرد شخصى بر روى نوروفيبروماتوز و MPNST باشد.

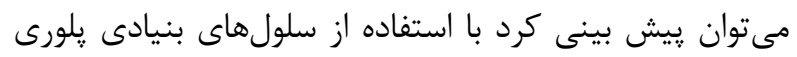

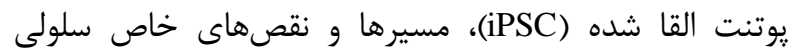
ناشى از از دست رفتن NF1 شناسايى شوند و در نتيجه كشف

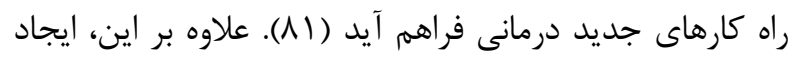

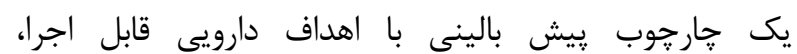

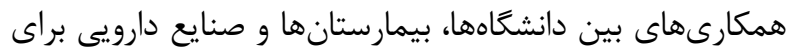
يياده سازى خط توليد داروهاى بالينى، فرصتهاى اميدوار كنندهاى براى درمان قريب الوقوع NF1 خواهد بود.
قرار گرفتهاند كه به موجب آن هر دو مهاركننده با تنظيم مقادير يروتئين درگير كننده تيروردوكسين (TXNIP) و در نتيجه مهار تيروردوكسين و فعال شدن سيخنال تنظيم كننده آيويتوز سبب مرگ سلولى مىشوند (ASK1) برومودومينها) بيان زنهاى ميتوتيك مورد نياز براى ريشرفت جرخه سلولى را تنظيم مى كند. در مطالعاتى نشان داده شده است كه MPNSTها حساسيت به مهاركنندههاى برومودامين BET مىيابد، كه استفاده از درمان تركيبى شامل مهار كنندههاى

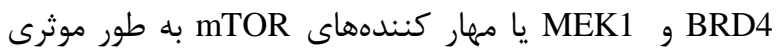
موجب افزايش ايجاد BIM يروآيويتوزى و افزايش مرگ سلولى در MPNST مىشوند (VV). تجزيه و تحليل ترانسكرييتوم نشان

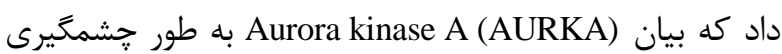
در MPNST افزايش يافته است، كه نشانگر آن است AURKA مى تواند هدف بالقوهاى براى درمان MPNST محسوب شود. در

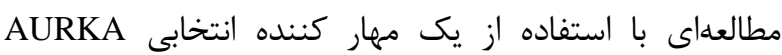
(MLN8237) بقاى موشهاى مبتلا به MPNST (افزايش يافت

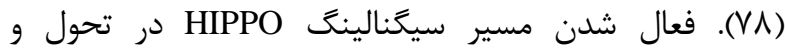
ييشرفت MPNSTs دخيل است. كينازهاى LATS1 و 2 و با فسفوريلاسيون TAZ / YAP موجب تنظيم منفى دين هاري مىشوند و در نتيجه از انتقال هسته اى آنها جلوگيرى مى كنند و با همكارى عاملهاى رونويسى موجب تنظيم رشد سلول

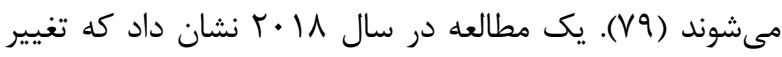
در بيان زن HAPPO-TAZ / YAP در MPNST انسان رخ مد مىدهد. در اين مطالعه با استفاده از داروى مهار كننده PDGFR (Verteporfin) TAZ/YAP رشد تومور كاهش يافت كه ييشنهاد كننده يك (Sorafenib) راهكار درمانى جديد براى MPNSTs محسوب مىشود (• ().

\section{نتيجهد گيرى و گُشم انداز}

از زمان كشف زن عامل NF1، ييشرفتهاى اساسى بسيارى در زمينه كاركرد نوروفيبرومين انجام شده است. با وجود اين كه

\section{REFERENCES}

1. Ruggieri M, Praticò AD, Caltabiano R, Polizzi A. Early history of the different forms of neurofibromatosis from ancient Egypt to the British Empire and beyond: First descriptions, medical curiosities, misconceptions, landmarks, and the persons behind the syndromes. Am J Med Genet Part A 2018;176:515-50.

2. Noori-Daloii MR, Kavoosi S, Rahimi Rad N. CRISPR/Cas9: high throughput genome editing molecular tool. Med Sci J Islamic Azad Univ 2017;27:223-36. [In Persian]

3. Kuiper M. Neurological and appearance-related symptoms in children with neurofibromatosis type 1 (NF1): The relationship between NF1 severity and cognitive and behavioural outcomes [MSc Thesis]. Leiden: Leiden University; 2011. 
4. Noori-Daloii M. Medical molecular genetics in the third millennium. Tehran: Samer and Nashre Akhar Publishing, 2009. [In Persian]

5. Costa DdS, de Paula JJ, Alvim-Soares Jr AM, Pereira PA, Malloy-Diniz LF, Rodrigues LO, et al. COMT Val158Met Polymorphism Is Associated with Verbal Working Memory in Neurofibromatosis Type 1. Front Hum Neurosci 2016;10:334.

6. Burris CK, Stier MA, Salamat S, Thomas S, Lauderdale S, Raven ML, et al. Neurofibromatosis type 1: a neuropsycho-cutaneous syndrome? Orbit 2018;37:208-11.

7. Dogra BB, Rana KS. Facial plexiform neurofibromatosis: a surgical challenge. Dermatol Online J 2013;4:195.

8. Barker D, Wright E, Nguyen K, Cannon L, Fain P, Goldgar D, et al. Gene for von Recklinghausen neurofibromatosis is in the pericentromeric region of chromosome 17. Science 1987;236:1100-2.

9. Seizinger B, Rouleau G, Ozelius L, Lane A, Faryniarz A, Chao M, et al. Genetic linkage of von Recklinghausen neurofibromatosis to the nerve growth factor receptor gene. Cell 1987;49:589-94

10. Wallace MR, Marchuk DA, Andersen LB, Letcher R, Odeh HM, Saulino AM, et al. Type 1 neurofibromatosis gene: identification of a large transcript disrupted in three NF1 patients. Science 1990;249:181-6.

11. Fain P, Goldgar D, Wallace M, Collins F, Wright E, Nguyen K, et al. Refined physical and genetic mapping of the NF1 region on chromosome 17. Am J Hum Genet 1989;45:721.

12. Collins FS, O'Connell P, Ponder BA, Seizinger BR. Progress towards identifying the neurofibromatosis (NF1) gene. Trends Genet 1989;5:217-21.

13. Menon AG, Ledbetter DH, Rich DC, Seizinger BR, Rouleau GA, Michels VF, et al. Characterization of a translocation within the von Recklinghausen neurofibromatosis region of chromosome 17. Genomics 1989;5:245-9.

14. Viskochil D, Buchberg AM, Xu G, Cawthon RM, Stevens J, Wolff RK, et al. Deletions and a translocation interrupt a cloned gene at the neurofibromatosis type 1 locus. Cell 1990;62:187-92.

15. Ratner N, Miller SJ. A RASopathy gene commonly mutated in cancer: the neurofibromatosis type 1 tumour suppressor. Nat Rev Cancer 2015;15:290.

16. Seminog OO, Goldacre MJ. Risk of benign tumours of nervous system, and of malignant neoplasms, in people with neurofibromatosis: population-based record-linkage study. Br J Cancer 2013;108:193.

17. Barron VA, Lou H. Alternative splicing of the neurofibromatosis type I pre-mRNA. Biosci Rep 2012;32:131-8.

18. Mitin N, Rossman KL, Der CJ. Signaling interplay in Ras superfamily function. Curr Biol 2005;15:R563-74.

19. McTaggart S. Isoprenylated proteins. Cell Mol Life Sci 2006;63:255-67.

20. Downward J. Targeting RAS signalling pathways in cancer therapy. Nat Rev Cancer 2003;3:11.

21. Goodsell DS. The molecular perspective: the ras oncogene. Oncologist 1999;4:263-4.

22. Hiatt KK, Ingram DA, Zhang Y, Bollag G, Clapp DW. Neurofibromin GTPase-activating protein-related domains restore normal growth in Nf1-/- cells. J Biol Chem 2001;276:7240-5.

23. Lavoie H, Therrien M. Regulation of RAF protein kinases in ERK signalling. Nat Rev Mol Cell Biol 2015;16:281.

24. Aramini JM, Vorobiev SM, Tuberty LM, Janjua H, Campbell ET, Seetharaman J, et al. The RAS-binding domain of human BRAF protein serine/threonine kinase exhibits allosteric conformational changes upon binding HRAS. Structure 2015;23:1382-93.

25. Hancock JF, Robert G. Ras plasma membrane signalling platforms. Biochem J 2005;389:1-11.

26. Welti S, Kühn S, D'angelo I, Brügger B, Kaufmann D, Scheffzek K. Structural and biochemical consequences of NF1 associated nontruncating mutations in the Sec14- PH module of neurofibromin. Hum Mutat 2011;32:191-7.

27. Mavrakis KJ, Zhu H, Silva RL, Mills JR, Teruya-Feldstein J, Lowe SW, et al. Tumorigenic activity and therapeutic inhibition of Rheb GTPase. Genes Dev 2008;22:2178-88.

28. Atala A. Re: mTORC1 Drives HIF-1 $\alpha$ and VEGF-A Signalling via Multiple Mechanisms Involving 4E-BP1, S6K1 and STAT3. J Urol 2016;195:524-5.

29. Ozawa T, Araki N, Yunoue S, Tokuo H, Feng L, Patrakitkomjorn S, et al. The neurofibromatosis type 1 gene product neurofibromin enhances cell motility by regulating actin filament dynamics via the Rho-ROCK-LIMK2-cofilin pathway. J Biol Chem 2005;280:39524-33. 
30. Gregory PE, Gutmann DH, Mitchell A, Park S, Boguski M, Jacks T, et al. Neurofibromatosis type 1 gene product (neurofibromin) associates with microtubules. Somatic cell Mol Genet 1993;19:265-74.

31. Kweh F, Zheng M, Kurenova E, Wallace M, Golubovskaya V, Cance WG. Neurofibromin physically interacts with the N- terminal domain of focal adhesion kinase. Mol Carcinog 2009;48:1005-17.

32. Tsai PI, Wang M, Kao HH, Cheng YJ, Walker JA, Chen RH, et al. Neurofibromin mediates FAK signaling in confining synapse growth at Drosophila neuromuscular junctions. J Neurosci 2012;32:16971-81.

33. Feng L, Yunoue S, Tokuo H, Ozawa T, Zhang D, Patrakitkomjorn S, et al. PKA phosphorylation and 14- 3- 3 interaction regulate the function of neurofibromatosis type I tumor suppressor, neurofibromin. FEBS Lett 2004;557:275-82.

34. Sadjadi A, Nouraie M, Mohagheghi MA, Mousavi-Jarrahi A, Malekezadeh R, Parkin DM. Cancer occurrence in Iran in 2002, an international perspective. Asian Pac J Cancer Prev 2005;6:359.

35. Korf BR. Malignancy in neurofibromatosis type 1. Oncologist 2000;5:477-85.

36. Zehou O, Fabre E, Zelek L, Sbidian E, Ortonne N, Banu E, et al. Chemotherapy for the treatment of malignant peripheral nerve sheath tumors in neurofibromatosis 1: a 10-year institutional review. Orphanet J Rare Dis 2013;8:127.

37. Kahn J, Gillespie A, Tsokos M, Ondos J, Dombi E, Camphausen K, et al. Radiation therapy in management of sporadic and neurofibromatosis type 1-associated malignant peripheral nerve sheath tumors. Front Oncol 2014;4:324.

38. Yang JC, Chang AE, Baker AR, Sindelar WF, Danforth DN, Topalian SL, et al. Randomized prospective study of the benefit of adjuvant radiation therapy in the treatment of soft tissue sarcomas of the extremity. J Clin Oncol 1998; 16:197-203.

39. Du X, Yang J, Ylipää A, Zhu Z. Genomic amplification and high expression of EGFR are key targetable oncogenic events in malignant peripheral nerve sheath tumor. J Hematol Oncol 2013;6:93.

40. Beert E, Brems H, Daniëls B, De Wever I, Van Calenbergh F, Schoenaers J, et al. Atypical neurofibromas in neurofibromatosis type 1 are premalignant tumors. Genes Chromosomes Cancer 2011;50:1021-32.

41. Noori-Daloii M, Zekri A. Aura kinase family roles in cancer diagnosis and treatment: a review article. Med Sci J Islamic Azad Univ 2011;21:71-81. [In Persian]

42. Upadhyaya M, Spurlock G, Thomas L, Thomas NS, Richards M, Mautner VF, et al. Microarray- based copy number analysis of neurofibromatosis type- 1 (NF1)- associated malignant peripheral nerve sheath tumors reveals a role for Rho-GTPase pathway genes in NF1 tumorigenesis. Hum Mutat 2012;33:763-76.

43. Tabone-Eglinger S, Bahleda R, Côté JF, Terrier P, Vidaud D, Cayre A, et al. Frequent EGFR positivity and overexpression in high-grade areas of human MPNSTs. Sarcoma 2008;2008.

44. Smith DC, Smith MR, Sweeney C, Elfiky AA, Logothetis C, Corn PG, et al. Cabozantinib in patients with advanced prostate cancer: results of a phase II randomized discontinuation trial. J Clin Oncol 2013;31:412.

45. Ohishi J, Aoki M, Nabeshima K, Suzumiya J, Takeuchi T, Ogose A, et al. Imatinib mesylate inhibits cell growth of malignant peripheral nerve sheath tumors in vitro and in vivo through suppression of PDGFR- $\beta$. BMC Cancer 2013;13:224.

46. Gudena V, Verma N, Post G, Kizziah M, Fenning R, Montero AJ. Metastatic chest wall malignant schwannoma responding to sorafenib: case report and literature review. Cancer Biol Ther 2008;7:810-3.

47. Ambrosini G, Cheema HS, Seelman S, Teed A, Sambol EB, Singer S, et al. Sorafenib inhibits growth and mitogenactivated protein kinase signaling in malignant peripheral nerve sheath cells. Mol Cancer Ther 2008;7:890-6.

48. Thomas LE, Winston J, Rad E, Mort M, Dodd KM, Tee AR, et al. Evaluation of copy number variation and gene expression in neurofibromatosis type-1-associated malignant peripheral nerve sheath tumours. Hum Genom 2015;9:3.

49. Teixeira F, Martinez-Palomo A, Riccardi V, Fernandez-Diez J. Vascular changes in cutaneous neurofibromas. Neurofibromatosis 1988;1:5-16.

50. Gesundheit B, Parkin P, Greenberg M, Baruchel S, Senger C, Kapelushnik J, et al. The role of angiogenesis in the transformation of plexiform neurofibroma into malignant peripheral nerve sheath tumors in children with neurofibromatosis type 1. J Pediatr Hematol Oncol 2010;32:548-53.

51. Rad E, Dodd K, Thomas L, Upadhyaya M, Tee A. STAT3 and HIF1 $\alpha$ signaling drives oncogenic cellular phenotypes in malignant peripheral nerve sheath tumors. Mol Cancer Res 2015;13:1149-60. 
52. Rahrmann EP, Watson AL, Keng VW, Choi K, Moriarity BS, Beckmann DA, et al. Forward genetic screen for malignant peripheral nerve sheath tumor formation identifies new genes and pathways driving tumorigenesis. Nature Genet 2013;45:756.

53. Watson AL, Rahrmann EP, Moriarity BS, Choi K, Conboy CB, Greeley AD, et al. Canonical Wnt $/ \beta$-catenin signaling drives human Schwann cell transformation, progression, and tumor maintenance. Cancer Discov 2013;3:67489.

54. Luscan A, Masliah-Planchon J, Laurendeau I, Ortonne N, Varin J, Lallemand F, et al. The activation of the WNT signalling pathway is a hallmark in Neurofibromatosis type 1 tumorigenesis. Clin Cancer Res 2013;20:358-71.

55. Curtin JC, Lorenzi MV. Drug discovery approaches to target Wnt signaling in cancer stem cells. Oncotarget 2010;1:552.

56. Bradtmöller M, Hartmann C, Zietsch J, Jäschke S, Mautner VF, Kurtz A, et al. Impaired Pten expression in human malignant peripheral nerve sheath tumours. PLoS One 2012;7:e47595.

57. Reilly KM. Extending the convergence of canonical Wnt signaling and classic cancer pathways for treatment of malignant peripheral nerve sheath tumors. Cancer discov 2013;3:610-2.

58. De Raedt T, Beert E, Pasmant E, Luscan A, Brems H, Ortonne N, et al. PRC2 loss amplifies Ras-driven transcription and confers sensitivity to BRD4-based therapies. Nature 2014;514:247.

59. Kirmizis A, Bartley SM, Farnham PJ. Identification of the Polycomb Group Protein SU (Z) 12 as a Potential Molecular Target for Human Cancer Therapy1. Mol Cancer Ther 2003;2:113-21.

60. Li H, Cai Q, Wu H, Vathipadiekal V, Dobbin ZC, Li T, et al. SUZ12 promotes human epithelial ovarian cancer by suppressing apoptosis via silencing HRK. Mol Cancer Res 2012;10:1462-72.

61. Pasmant E, Masliah-Planchon J, Lévy P, Laurendeau I, Ortonne N, Parfait B, et al. Identification of genes potentially involved in the increased risk of malignancy in NF1-microdeleted patients. Mol Med 2011;17:79.

62. Liu C, Shi X, Wang L, Wu Y, Jin F, Bai C, et al. SUZ12 is involved in progression of non-small cell lung cancer by promoting cell proliferation and metastasis. Tumor Biol 2014;35:6073-82.

63. Noori-Daloii M, Alvandi E. Micro RNA: Small but full of mystery and use: a review article. Tehran Univ Med J 2006;64:5-18. [In Persian]

64. Noori-Daloii MR, Nejatizadeh A. MicroRNA in disease and health: diagnostic and therapeutic potentials. In: Kang C, Ed. Gene therapy- development and future perspectives. USA: InThec; 2011. P. 93-120

65. Völkel P, Dupret B, Le Bourhis X, Angrand PO. Diverse involvement of EZH2 in cancer epigenetics. Am J Transl Res 2015;7:175.

66. Masliah-Planchon J, Pasmant E, Luscan A, Laurendeau I, Ortonne N, Hivelin M, et al. MicroRNAome profiling in benign and malignant neurofibromatosis type 1 -associated nerve sheath tumors: evidences of PTEN pathway alterations in early NF1 tumorigenesis. BMC Genomics 2013;14:473.

67. Calin GA, Sevignani C, Dumitru CD, Hyslop T, Noch E, Yendamuri S, et al. Human microRNA genes are frequently located at fragile sites and genomic regions involved in cancers. Proc Natl Acad Sci U S A 2004;101:29993004.

68. Presneau N, Eskandarpour M, Shemais T, Henderson S, Halai D, Tirabosco R, et al. MicroRNA profiling of peripheral nerve sheath tumours identifies miR-29c as a tumour suppressor gene involved in tumour progression. Br $\mathrm{J}$ Cancer 2013;108:964.

69. Noori-Daloii MR, Vand Rajabpour F. Roles of miRNAs in gene expression regulation, apoptosis, diagnosis and treatment of cancer. Med Sci J Islamic Azad Univ 2011;21:151-61. [In Persian]

70. Walker JA, Upadhyaya M. Emerging therapeutic targets for neurofibromatosis type 1. Expert Opin Ther Targets 2018;22:419-37.

71. Liang XH, Sun H, Shen W, Wang S, Yao J, Migawa MT, et al. Antisense oligonucleotides targeting translation inhibitory elements in 5' UTRs can selectively increase protein levels. Nucleic Acids Res 2017;45:9528-46.

72. Gori JL, Hsu PD, Maeder ML, Shen S, Welstead GG, Bumcrot D. Delivery and specificity of CRISPR/Cas9 genome editing technologies for human gene therapy. Hum Gene Ther 2015;26:443-51.

73. Hanemann CO, Blakeley JO, Nunes FP, Robertson K, Stemmer-Rachamimov A, Mautner V, et al. Current status and recommendations for biomarkers and biobanking in neurofibromatosis. Neurology 2016;87:S40-8. 
74. Jones RE, Grimstead JW, Sedani A, Baird D, Upadhyaya M. Telomere erosion in NF1 tumorigenesis. Oncotarget 2017;8:40132.

75. De Raedt T, Walton Z, Yecies JL, Li D, Chen Y, Malone CF, et al. Exploiting cancer cell vulnerabilities to develop a combination therapy for ras-driven tumors. Cancer cell 2011;20:400-13.

76. Malone CF, Emerson C, Ingraham R, Barbosa W, Guerra S, Yoon H, et al. mTOR and HDAC inhibitors converge on the TXNIP/thioredoxin pathway to cause catastrophic oxidative stress and regression of RAS-driven tumors. Cancer Discov 2017;7:1450-63.

77. Varin J, Poulain L, Hivelin M, Nusbaum P, Hubas A, Laurendeau I, et al. Dual mTORC1/2 inhibition induces antiproliferative effect in NF1-associated plexiform neurofibroma and malignant peripheral nerve sheath tumor cells. Oncotarget 2016;7:35753.

78. Patel AV, Eaves D, Jessen WJ, Rizvi TA, Ecsedy JA, Qian MG, et al. Ras-driven transcriptome analysis identifies aurora kinase $\mathrm{A}$ as a potential malignant peripheral nerve sheath tumor therapeutic target. Clin Cancer Res 2012;18:5020-30.

79. Varelas X. The Hippo pathway effectors TAZ and YAP in development, homeostasis and disease. Development 2014;141(8):1614-26.

80. Wu LMN, Deng Y, Wang J, Zhao C, Wang J, Rao R, et al. Programming of Schwann cells by Lats1/2-TAZ/YAP signaling drives malignant peripheral nerve sheath tumorigenesis. Cancer cell 2018;33:292-308.

81. Wegscheid ML, Anastasaki C, Gutmann DH. Human stem cell modeling in neurofibromatosis type 1 (NF1). Exp Neurol 2018;299:270-80. 